\title{
Validation of the TOLNet lidars: the Southern California Ozone Observation Project (SCOOP)
}

\author{
Thierry Leblanc $^{1}$, Mark A. Brewer ${ }^{1}$, Patrick S. Wang ${ }^{1}$, Maria Jose Granados-Muñoz ${ }^{1,2}$, Kevin B. Strawbridge ${ }^{3}$, \\ Michael Travis $^{3}$, Bernard Firanski ${ }^{3}$, John T. Sullivan ${ }^{4}$, Thomas J. McGee ${ }^{4}$, Grant K. Sumnicht ${ }^{5}$, Laurence W. Twigg ${ }^{5}$, \\ Timothy A. Berkoff ${ }^{6}$, William Carrion ${ }^{6}$, Guillaume Gronoff ${ }^{6,7}$, Ali Aknan ${ }^{6}$, Gao Chen $^{6}$, Raul J. Alvarez ${ }^{8}$, \\ Andrew O. Langford ${ }^{8}$, Christoph J. Senff ${ }^{9}$, Guillaume Kirgis ${ }^{9}$, Matthew S. Johnson ${ }^{10}$, Shi Kuang ${ }^{11}$, and \\ Michael J. Newchurch ${ }^{11}$ \\ ${ }^{1}$ Jet Propulsion Laboratory, California Institute of Technology, Wrightwood, CA 92397, USA \\ ${ }^{2}$ Remote Sensing Laboratory/CommSensLab, Universitat Politècnica de Catalunya, Barcelona, Spain \\ ${ }^{3}$ Air Quality Processes Research Section, Environment and Climate Change Canada, Toronto, ON, Canada \\ ${ }^{4}$ NASA Goddard Space Flight Center, Greenbelt, MD, USA \\ ${ }^{5}$ Science Systems and Applications Inc., Lanham, MD, USA \\ ${ }^{6}$ NASA Langley Research Center, Hampton, VA, USA \\ ${ }^{7}$ Science Systems and Applications Inc, Hampton, VA, USA \\ ${ }^{8}$ NOAA Earth System Research Laboratory (ESRL) Chemical Sciences Division, Boulder, CO, USA \\ ${ }^{9}$ University of Colorado Cooperative Institute for Research in Environmental Sciences (CIRES) at the NOAA Earth System \\ Research Laboratory (ESRL) Chemical Sciences Division, Boulder, CO, USA \\ ${ }^{10}$ NASA Ames Research Center, Moffett Field, CA, USA \\ ${ }^{11}$ University of Alabama in Huntsville, AL, USA
}

Correspondence: Thierry Leblanc (thierry.leblanc@jpl.nasa.gov)

Received: 20 July 2018 - Discussion started: 20 August 2018

Revised: 16 October 2018 - Accepted: 22 October 2018 - Published: 12 November 2018

\begin{abstract}
The North America-based Tropospheric Ozone Lidar Network (TOLNet) was recently established to provide high spatiotemporal vertical profiles of ozone, to better understand physical processes driving tropospheric ozone variability and to validate the tropospheric ozone measurements of upcoming spaceborne missions such as Tropospheric Emissions: Monitoring Pollution (TEMPO). The network currently comprises six tropospheric ozone lidars, four of which are mobile instruments deploying to the field a few times per year, based on campaign and science needs. In August 2016, all four mobile TOLNet lidars were brought to the fixed TOLNet site of JPL Table Mountain Facility for the 1-week-long Southern California Ozone Observation Project (SCOOP). This intercomparison campaign, which included $400 \mathrm{~h}$ of lidar measurements and 18 ozonesonde launches, allowed for the unprecedented simultaneous validation of five of the six TOLNet lidars. For measurements between 3 and $10 \mathrm{~km}$ a.s.1., a mean difference of $0.7 \mathrm{ppbv}(1.7 \%)$, with a
\end{abstract}

root-mean-square deviation of $1.6 \mathrm{ppbv}$ or $2.4 \%$, was found between the lidars and ozonesondes, which is well within the combined uncertainties of the two measurement techniques. The few minor differences identified were typically associated with the known limitations of the lidars at the profile altitude extremes (i.e., first $1 \mathrm{~km}$ above ground and at the instruments' highest retrievable altitude). As part of a large homogenization and quality control effort within the network, many aspects of the TOLNet in-house data processing algorithms were also standardized and validated. This thorough validation of both the measurements and retrievals builds confidence as to the high quality and reliability of the TOLNet ozone lidar profiles for many years to come, making TOLNet a valuable ground-based reference network for tropospheric ozone profiling. 


\section{Introduction}

Although vital in the stratosphere, ozone has long been recognized as an air pollutant near the Earth's surface, causing health problems for humans and vegetation at high concentration (World Health Organization, 2003). Tropospheric ozone is also a short-lived greenhouse gas impacting climate, contributing to the Earth's global warming (IPCC, 2013). Despite significant regulatory efforts and pollution-control programs developed over the past 20 years in the most densely populated regions of the globe (e.g., Europe, North America, and more recently Asia), recent reports of continuing free-tropospheric ozone increases, for example in the western United States (Cooper et al., 2012; Granados-Muñoz and Leblanc, 2016; Gaudel et al., 2018), have triggered the need to enhance our tropospheric ozone observation capabilities. In this context, the North America-based Tropospheric Ozone Lidar Network (TOLNet, https://www-air.larc.nasa. gov/missions/TOLNet/, last access: 7 November 2018) was recently established to provide high spatiotemporal observations of tropospheric ozone to (1) better understand physical processes driving the ozone budget in various meteorological and environmental conditions, and (2) validate the tropospheric ozone measurements of upcoming spaceborne missions such as TEMPO (Tropospheric Emissions: Monitoring of POllution; http://tempo.si.edu, last access: 7 November 2018) (Zoogman et al., 2014; Johnson et al., 2018) or TROPOMI (TROPOspheric Monitoring Instrument, http://www.tropomi.eu/, last access: 7 November 2018). As of 2018, the network comprises six high-performance ozone differential absorption lidars (DIAL), namely the Canadabased Autonomous Mobile Ozone Lidar for Tropospheric Experiments (AMOLITE) (Strawbridge et al., 2018), the National Aeronautics and Space Administration (NASA) Langley Mobile Ozone Lidar (LMOL) (De Young et al., 2017), the University of Alabama in Huntsville Rocket-city $\mathrm{O}_{3}$ Quality Evaluation in the Troposphere lidar $\left(\mathrm{RO}_{3} \mathrm{QET}\right)$ (Kuang et al., 2013), the JPL Table Mountain tropospheric ozone lidar (TMTOL) (McDermid et al., 2002), the National Oceanic and Atmospheric Administration (NOAA) Tunable Optical Profiler for Aerosol and oZone Lidar (TOPAZ) (Alvarez et al., 2011), and the NASA Goddard Space Flight Center mobile Tropospheric Ozone Lidar (TROPOZ) (Sullivan et al., 2014). Four of these lidars (AMOLITE, LMOL, TOPAZ, and TROPOZ) are mobile systems for deployment at remote locations, depending on field campaign and science needs of the moment. The remaining two systems operate at fixed locations: the $\mathrm{RO}_{3} \mathrm{QET}$ system located at the University of Alabama in Huntsville campus and the TMTOL system located at the JPL Table Mountain Facility (TMF) in Southern California.

In August 2016, taking advantage of a favorable field deployment calendar, all four TOLNet mobile lidars were brought to the fixed TOLNet site of JPL-TMF for a 1-weeklong intercomparison campaign that allowed for the unprece- dented simultaneous validation of five of the six TOLNet lidars: the Southern California Ozone Observation Project (SCOOP). As part of the international Network for the Detection of Atmospheric Composition Change (NDACC) (De Mazière et al., 2018), TMF is a well-recognized research facility for the validation of atmospheric remotesensing instrumentation (e.g., Leblanc et al., 2011; McDermid et al., 1995). In addition to its three NDACC lidars (one of them being TMTOL), the facility hosts pressuretemperature-humidity (PTU) sonde and ozonesonde launch systems, radiometers, spectrometers, and surface composition and weather instruments. In support of the SCOOP campaign, several surface ozone monitoring instruments were operated at the site $24 / 7$, and 18 ozonesondes were launched and used as a reference transfer for the validation of the TOLNet lidars.

Prior to this study, three of the TOLNet lidars (TOPAZ, TROPOZ, and LMOL) participated in the Deriving Information on Surface Conditions from COlumn and VERtically Resolved Observations Relevant to Air Quality (DISCOVER-AQ) field campaign in Colorado in 2014, showing a mean relative difference within $4 \%$ between these three lidars (Wang et al., 2017). However, after the DISCOVER-AQ campaign, the TOPAZ and LMOL systems underwent significant hardware upgrades resulting in better stability, higher precision, and much higher measurable altitudes.

This paper reviews the TOLNet lidar measurement and retrieval validation efforts undergone prior to, during, and immediately after the SCOOP campaign, which eventually led to the current routine production of homogeneous, qualitycontrolled ozone profiles from the AMOLITE, LMOL, TMTOL, TOPAZ, and TROPOZ lidars. After a brief technical description of the participating TOLNet lidar instruments (Sect. 2), the campaign operational details relevant to the validation of the lidars are reviewed (Sect. 3). The validation of the TOLNet data processing algorithms is summarized in Sect. 4. The blind intercomparison of the lidar and ozonesonde measurements during SCOOP is presented in Sect. 5. This dual algorithm-measurement validation approach allows the separation of ozone biases owing to the data processing on one hand and to the measurement itself on the other hand. The final outcome is presented in Sect. 6, and all the results are summarized in Sect. 7. Conclusions are provided in Sect. 8 together with a brief discussion on the possible avenues of future TOLNet development.

\section{Participating TOLNet lidar and other instruments}

Five of the six TOLNet lidars participated in the SCOOP campaign. During the few months preceding the campaign, some of these lidars had undergone a few instrument configuration changes, and further validation therefore turned out to be timely. By the end of the SCOOP campaign, and 
as will be demonstrated in this article, all five lidar systems proved to provide excellent quality ozone profiles, and their performance during the SCOOP campaign is believed to remain stable for years to come. Each instrument is briefly described below. Key transmitter and receiver specifications for all ozone lidar systems are compiled in Table 1, and key data acquisition settings in Table 2 .

\subsection{The Canadian AMOLITE lidar}

The Autonomous Mobile Ozone Lidar Instrument for Tropospheric Experiments (AMOLITE) was designed and built by Environment and Climate Change Canada (Strawbridge et al., 2018), leveraging on a decade-long past experience of building autonomous mobile aerosol lidars (Strawbridge, 2013). Space in the $2.1 \times 4.3 \mathrm{~m}(\mathrm{~W} \times \mathrm{L})$ trailer was optimized to house two dual-laser lidars, one dedicated to the measurement of tropospheric ozone and the other one to the measurement of aerosol and water vapor. Weather instruments (including a precipitation sensor), radar interlock, and sophisticated heating/cooling systems are among the many safety components necessary to ensure continuous, unattended remote operations. Each of the two lidar systems comprises dual lasers to help minimize data gaps in case of equipment failures.

The ozone system which produced all AMOLITE ozone profiles presented here comprises two Nd:YAG lasers producing $45 \mathrm{~mJ}$ per pulse at $266 \mathrm{~nm}$ and $20 \mathrm{~Hz}$. The $266 \mathrm{~nm}$ beam is sent through a $1 \mathrm{~m}$ long cell filled with $\mathrm{CO}_{2}$ (Nakazato et al., 2007) for Raman shifting and then directed vertically by a steering mirror, which can be remotely controlled for beam-telescope re-alignment. Backscattered light is collected on a $35 \mathrm{~cm}$ diameter Schmidt-Cassegrain telescope and spectrally separated to two photomultiplier tubes (PMTs) collecting the light at the Raman-shifted wavelengths of 287 and $299 \mathrm{~nm}$, which correspond to the second and third Stokes lines of $\mathrm{CO}_{2}$, respectively. The PMT signals are time-sampled at $25 \mathrm{~ns}$ intervals (i.e., $3.75 \mathrm{~m}$ resolution) by a Licel analog and photon-counting transient recorder (12 bit digitizer). During nighttime and for a $5 \mathrm{~min}$ integration time, the combination of laser power, telescope size, and receiver efficiency allows for ozone measurements between $400 \mathrm{~m}$ above ground and $15 \mathrm{~km}$ altitude. AMOLITE operates $24 \mathrm{~h}$ a day, 7 days a week except during precipitation. The system is operated remotely, and the data are updated hourly to a website providing near-real-time capability.

\subsection{The NASA-LaRC LMOL lidar}

The Langley Mobile Ozone Lidar (LMOL) is a ground-based tropospheric profiling ozone lidar system housed in a mobile trailer that has participated in air quality studies since 2014 (Young et al., 2017). Like the other TOLNet lidar systems, LMOL relies on ultraviolet (UV) pulsed laser source that produces two wavelengths allowing for calculation of $\mathrm{O}_{3}$ concentration profiles from atmospheric differential absorption (Browell et al., 1985). The laser transmitter is similar to the NOAA system and consists of a custom-built Ce:LiCAF tunable UV oscillator that is pumped by a frequency-doubled $(527 \mathrm{~nm})$ commercially available $\mathrm{Nd}$ :YLF laser operating at a $1 \mathrm{kHz}$ repetition rate. For the multi-wavelength UV pulse generation, a high-reflectivity rear cavity mirror mounted on a servo-controlled galvanometer motor allows for rapid tuning of the Ce:LiCAF output between two wavelengths suitable for ozone DIAL measurements. During the SCOOP campaign the on- and offline DIAL wavelengths 287.1 and 292.7 were used and remained stable for the duration of the campaign. Light was transmitted in a zenith direction into the atmosphere from a hatch on the trailer roof at about $100 \mu \mathrm{J}$ pulse $\mathrm{s}^{-1}$, alternating pulse to pulse between the onand offline wavelengths $(500 \mathrm{~Hz}$ each).

Backscattered light from the atmosphere was collected by a co-aligned $40 \mathrm{~cm}$ diameter fiber-coupled Newtonian telescope with a $1.4 \mathrm{mrad}$ field of view, providing measurements from 0.6 to $8 \mathrm{~km}$ in altitude. The fiber output from the $40 \mathrm{~cm}$ telescope was connected to a light-tight enclosure containing a collimating optic, a pair of UV band-pass filters in series (280-295 $\mathrm{nm}$ spectral window) that were integrated with Hamamatsu PMT R7400-U03 detector. The PMT output was connected to a single-channel, 12 bit Licel data system that provided simultaneous analog and photon-counting outputs. The Licel system memory was synchronously gated with the alternating wavelength pulses, to separately capture profiles for the on- and offline data, and subsequently recorded by the instrument computer system for processing of raw signals into calibrated ozone profiles.

The processing of profiles was implemented following the standard DIAL technique (Browell et al., 1985). Raw signals, both analog and photon counting, are backgroundsubtracted and range-squared before application of a singlepass Savitzky-Golay filter (Leblanc et al., 2016a, and references therein); the more points used in the filter, the lower the resolution. Analog and photon-counting channels are merged together to provide a single optimized profile for range and signal-to-noise performance (Leblanc et al., 2016b; Zhang et al., 2014; Newsom et al., 2009). Ozone cross sections along with pressure and temperature information are used as part of the filter process to extract ozone mixing ratio as a function of altitude. The process is repeated for each new profile on a 5-10 min temporally averaged basis, to provide a continuous curtain display on the evolution of ozone vertical distribution during the course of a day. From a data analysis perspective, the more the data are averaged vertically, the lower the noise, but at the expense of the vertical resolution. A realtime data display was also available, allowing for display of the system-generated ozone curtain profiles as they are collected, for immediate feedback on atmospheric observations. This display was also linked over the Internet and could be remotely monitored, along with other system parameters. 
Table 1. TOLNet ozone lidar instrument configuration used during SCOOP.

\begin{tabular}{|c|c|c|c|c|c|}
\hline & AMOLITE & LMOL & TMTOL & TOPAZ & TROPOZ \\
\hline Laser type & $\begin{array}{l}\text { Nd:YAG } \\
\text { quadrupled }\end{array}$ & $\begin{array}{l}\text { Ce:LiCAF } \\
\text { tunable }\end{array}$ & $\begin{array}{l}\text { Nd:YAG } \\
\text { quadrupled }\end{array}$ & $\begin{array}{l}\text { Ce:LiCAF } \\
\text { tunable }\end{array}$ & $\begin{array}{l}\text { Nd:YAG } \\
\text { quadrupled }\end{array}$ \\
\hline Laser wavelength (nm) & 266.0 & $280-298$ & 266.0 & $285-310$ & 266.0 \\
\hline Laser rep. rate $(\mathrm{Hz})$ & 20 & $1000 / 2$ & 30 & $1000 / 3$ & 50 \\
\hline $\begin{array}{l}\text { Power at DIAL } \\
\text { wavelengths }(\mathrm{W})\end{array}$ & 0.9 & 0.075 & 1.1 & 0.03 & 0.8 \\
\hline Pulse energy (mJ) & 45 & 0.15 & 40 & 0.05 & 15 \\
\hline Raman cell & $\begin{array}{l}\mathrm{CO}_{2} \text { second and } \\
\text { third Stokes }\end{array}$ & N/A & $\begin{array}{l}\mathrm{H}_{2} \text { first Stokes } \\
\mathrm{D}_{2} \text { first Stokes }\end{array}$ & N/A & $\begin{array}{l}\mathrm{H}_{2} \text { first Stokes } \\
\mathrm{D}_{2} \text { first Stokes }\end{array}$ \\
\hline $\begin{array}{l}\text { DIAL wavelengths } \\
\text { during SCOOP }(\mathrm{nm})\end{array}$ & $\begin{array}{l}\text { On: } 287.2 \\
\text { Off: } 299.1\end{array}$ & $\begin{array}{l}\text { On: } 287.1 \\
\text { Off: } 292.7\end{array}$ & $\begin{array}{l}\text { On: } 288.9 \\
\text { Off: } 299.1\end{array}$ & $\begin{array}{l}\text { On: } 286-287 \\
\text { Off: } 293-294\end{array}$ & $\begin{array}{l}\text { On: } 288.9 \\
\text { Off: } 299.1\end{array}$ \\
\hline $\begin{array}{l}\text { Direction of } \\
\text { emission }\end{array}$ & $\begin{array}{l}\text { Fixed } \\
\text { zenith }\end{array}$ & $\begin{array}{l}\text { Fixed } \\
\text { zenith }\end{array}$ & $\begin{array}{l}\text { Fixed } \\
\text { zenith }\end{array}$ & $\begin{array}{l}\text { Scanning } \\
2^{\circ}-\text { zenith }\end{array}$ & $\begin{array}{l}\text { Fixed } \\
\text { zenith }\end{array}$ \\
\hline $\begin{array}{l}\text { Telescope } \\
\text { size }\end{array}$ & $1 \times 35 \mathrm{~cm}$ & $1 \times 40 \mathrm{~cm}$ & $\begin{array}{l}1 \times 91 \mathrm{~cm} \\
2 \times 5 \mathrm{~cm}\end{array}$ & $1 \times 50 \mathrm{~cm}$ & $\begin{array}{l}1 \times 45 \mathrm{~cm} \\
4 \times 2.5 \mathrm{~cm}\end{array}$ \\
\hline $\begin{array}{l}\text { Spectral } \\
\text { separation }\end{array}$ & $2 \times \mathrm{IF}$ & $1 \times \mathrm{SWP}$ & $\begin{array}{l}2 \times \mathrm{SWP} \\
4 \times \mathrm{IF}\end{array}$ & N/A & $6 \times \mathrm{IF}$ \\
\hline Detectors & $\begin{array}{l}2 \times \text { PMT } \\
\text { R7400U-03 }\end{array}$ & $\begin{array}{l}1 \times \text { PMT } \\
\text { R7400-U03 }\end{array}$ & $\begin{array}{l}4 \times \text { PMT } \\
\text { H5783P-06 }\end{array}$ & $\begin{array}{l}2 \times \text { PMT } \\
\text { HP9880-110 }\end{array}$ & $\begin{array}{l}6 \times \text { PMT } \\
\text { HP9880-110 }\end{array}$ \\
\hline $\begin{array}{l}\text { Data } \\
\text { recorders }\end{array}$ & $\begin{array}{l}2 \times \text { Licel TR } \\
\text { ADC } 12 \text { bits } \\
\text { PC } 250 \mathrm{MHz}\end{array}$ & $\begin{array}{l}1 \times \text { Licel TR } \\
\text { ADC } 12 \text { bits } \\
\text { PC } 250 \mathrm{MHz}\end{array}$ & $\begin{array}{l}4 \times \text { Licel TR } \\
\text { ADC } 16 \text { bits } \\
\text { PC } 250 \mathrm{MHz}\end{array}$ & $\begin{array}{l}2 \times \text { Licel TR } \\
\text { ADC } 16 \text { bits } \\
\text { PC } 250 \mathrm{MHz}\end{array}$ & $\begin{array}{l}6 \times \text { Licel TR } \\
\text { ADC } 12 \text { bits } \\
\text { PC } 250 \mathrm{MHz}\end{array}$ \\
\hline
\end{tabular}

ADC: analog-to-digital converter; PC: photon counting; PMT: photomultiplier; TR: transient recorder.

It is important to note that LMOL was originally configured to only collect data in the lower troposphere, and hence the data system range configuration was limited to $18 \mathrm{~km}$. The background subtraction value is determined from approximately the last $2 \mathrm{~km}$ of the data collection window. Ordinarily this does not pose a problem; however the SCOOP type analyses can reveal a bias error in LMOL due to residual laser light being captured in the range bins used for background value determination. This is particularly true for extended temporal averaging ( $>30 \mathrm{~min}$ ) at high altitude $(>9 \mathrm{~km})$ at nighttime, where this can result in systematic error $>10 \%$. Since the SCOOP campaign, a new data system card was purchased and data system configuration implemented that eliminates these effects.

Since the SCOOP campaign, there are a number of instrument improvements that have been implemented that further enhance the capabilities of the LMOL system. These include implementation of a second, smaller-diameter widefield telescope to allow measurements in the $120-1000 \mathrm{~m}$ altitude range (Farris et al., 2018; Gronoff et al., 2018), replacement of the outdated PMT with Hamamatsu model R9880U-113 and a new transmission configuration and roof window system to enable continuous unattended measurements. Since SCOOP, the LMOL system has successfully participated in three additional field deployments.

\subsection{The NASA-JPL TMTOL lidar}

The JPL-TMF tropospheric ozone lidar (TMTOL) is the third of four lidars designed at JPL for the long-term monitoring of atmospheric composition, thus contributing to the international network NDACC since 1999 (McDermid et al., 2002). Over the course of nearly 20 years, the system has gone through several hardware and operational modifications.

The emitter comprises a quadrupled Nd:YAG laser producing two beams of approximately $1 \mathrm{~W}$ each at $266 \mathrm{~nm}$, at a repetition rate of $30 \mathrm{~Hz}$. Each beam is sent through a Raman cell, one cell filled with hydrogen and the other with deuterium, to shift the wavelength to 299.1 and $288.9 \mathrm{~nm}$, respectively. The two beams are expanded five times to reduce their divergence (to less than $1 \mathrm{mrad}$ ) and to make them eyesafe as soon as they are transmitted outside the lidar building.

The optical receiver comprises a large Newtonian telescope (91 cm diameter, $2.4 \mathrm{~m}$ focal length) coupled with a 
dual optical fiber sending the lidar high-intensity returns to a polychromator. Two small telescopes ( $5 \mathrm{~cm}$ diameter), each aligned to one of the transmitted beams, are used to collect the near-range (low-intensity) signals. For each small telescope the light is focused at the entrance of an optical fiber and sent to the polychromator. This latter comprises four independent optical paths determined by the position of the fibers' output, corresponding to two high-intensity and two low-intensity channels. Until 2012, a mechanical chopper with four slits coinciding with the position of the fibers' outputs blocked the transmission of the strongest returns (lowest $1 \mathrm{~km}$ ) from the large telescope fibers. Since 2012, the chopper wheel has been kept in a fixed open position allowing the returns from all altitudes for all four fibers' outputs to be transmitted. The light output from each fiber is transmitted through a dichroic beam splitter reflecting shorter wavelengths (Hartley band), a collimating lens, an interference filter ( $2 \mathrm{~nm}$ full width at half maximum (FWHM) centered at 289 or $299 \mathrm{~nm}$, depending on the fiber considered), and a focusing lens, before it reaches the surface of a photomultiplier tube (Hamamatsu H5783P-06). Although of old age, these photomultipliers have proved to be very reliable in the long term, with minimal signal-induced noise despite the presence of high intensity returns.

The data acquisition system includes four joint analogphoton-counting transient recorders (Licel) allowing a vertical sampling of $7.5 \mathrm{~m}$ between the ground and $60 \mathrm{~km}$ altitude. The 16 bit analog signals are not used in the current SCOOP data analysis, and only the results coming from the photoncounting channels are shown here.

Before data acquisition, the two emitted beams are aligned to the large telescope mirror axis using a computer-controlled motion controller and actuators changing the orientation of the two transmitting mirrors. When properly aligned, the low-intensity channels can be used down to an altitude range of $600 \mathrm{~m}$ above ground, i.e., $2.9 \mathrm{~km}$ a.s.1.

During the SCOOP campaign the lidar typical altitude range after combining the low- and high-intensity channels extends from 2.9 to $15 \mathrm{~km}$ a.s.l. During the night, the top altitude typically reaches $18 \mathrm{~km}$ for a $30 \mathrm{~min}$ averaged profile. It is extended to $25 \mathrm{~km}$ by adding another DIAL pair of channels using the $299 \mathrm{~nm}$ high-intensity signal of TMTOL as the absorbed signal and the low-intensity $355 \mathrm{~nm}$ signal of the co-located NDACC water vapor Raman lidar as the nonabsorbed signal.

In routine operation mode, the raw signals are saved every $5 \mathrm{~min}$. They are then averaged to the desired vertical and temporal resolutions based on the science needs. For NDACC, the lidar routinely operates $2 \mathrm{~h}$ per night, 4-5 nights per week, year-round. The $2 \mathrm{~h}$ averaged (nighttime-only) ozone profiles are archived systematically at the NDACC Data Archive Center, forming a long-term dataset of more than 2000 profiles $(3-25 \mathrm{~km})$ since 1999. For the SCOOP campaign, the lidar operation was extended to all times of the day, with ozone profiles reaching a $8-10 \mathrm{~km}$ top altitude dur- ing the brightest hours of the day and $15-25 \mathrm{~km}$ top altitude at nighttime. During the SCOOP campaign, the only hardware configuration difference with the description of McDermid et al. (2002) is the discontinued use of the chopper and the newer Licel system.

\subsection{The NOAA TOPAZ lidar}

The Tunable Optical Profiler for Aerosol and oZone (TOPAZ) lidar is a compact differential absorption lidar for measurement of ozone concentrations and aerosol backscatter in the lower troposphere that was originally designed (2006) as a nadir-viewing airborne instrument for the NOAA Twin Otter aircraft (Alvarez et al., 2011). The airborne system was deployed in the 2006 TexAQS (Senff, 2010) and 2010 CalNex (Langford et al., 2012) campaigns before being converted for zenith-viewing ground-based operation from a medium box truck in 2012 with an external turning mirror for slant path measurements within the lowest levels of the boundary layer. The truck-based system has been deployed to several field campaigns, including the 2013 Las Vegas Ozone Study (Langford et al., 2015).

Like the LMOL system, the TOPAZ transmitter is built on a rapidly tunable $(285-310 \mathrm{~nm})$, all-solid-state Ce:LiCAF laser pumped by a frequency-quadrupled, diode-pumped Nd:YLF laser. The TOPAZ laser also operates at high pulse repetition rates $(1000 \mathrm{~Hz}$ ) and low pulse energy (average of $50 \mu \mathrm{J}$ pulse $\mathrm{e}^{-1}$, with $100 \mathrm{~ns}$ pulse width) but sequentially tunes between three different wavelengths, giving an effective pulse repetition rate of $333 \mathrm{~Hz}$. Typical operation is with laser pulses near 287, 290, and $293 \mathrm{~nm}$ emitted sequentially and transmitted coaxially with the receiver telescope. The receiver uses a $0.5 \mathrm{~m}$ diameter Newtonian telescope to direct the backscattered lidar signal to two photomultiplier detectors with wide/narrow $(3.0 / 1.5 \mathrm{mrad})$ field of view for a nearfield/far-field channel with a power split of $10 \% / 90 \%$, respectively. The upward-looking telescope is located beneath a port in the truck roof that is capped by a large computerdriven mirror that can direct the coaxial transmitted and return beams along angles ranging from -5 to $30^{\circ}$ elevation. The turning mirror can also move out of the beam path to allow vertical data collection. Measurements taken at several angles (typically, 2, 6, 20, and $90^{\circ}$ elevation), along with an assumption of horizontal homogeneity, allow the combined profiles to extend from near ground level to the maximum vertical range (approximately 5-6 km a.g.l. during the day and $8-9 \mathrm{~km}$ a.g.l. at night). The scanner azimuth direction is fixed but adjustable according to the site and experiment requirements. A recent (2016) upgrade from the original fieldprogrammable-gate-array-based data acquisition system developed for aircraft operation to a new Licel hybrid data collection system has been implemented which includes both analog-mode (16 bit, $20 \mathrm{MS} \mathrm{s}^{-1}$ ) and photon-counting (to $250 \mathrm{MHz}$ ) detection along with new PMTs. This upgrade has significantly improved the useful signal range as described 
Table 2. TOLNet ozone lidar data acquisition configuration used during SCOOP.

\begin{tabular}{llllll}
\hline & AMOLITE & LMOL & TMTOL & TOPAZ & TROPOZ \\
\hline $\begin{array}{l}\text { Data acquisition } \\
\text { software }\end{array}$ & $\begin{array}{l}\text { Custom } \\
\text { 2 ADC channels } \\
2 \text { PC channels }\end{array}$ & $\begin{array}{l}\text { Licel } \\
\text { 2 ADC channels } \\
2 \text { PC channels }\end{array}$ & $\begin{array}{l}\text { Custom } \\
4 \text { ADC channels } \\
4 \text { PC channels }\end{array}$ & $\begin{array}{l}\text { Licel } \\
\text { 2 ADC channels } \\
2 \text { PC channels }\end{array}$ & $\begin{array}{l}\text { Licel } \\
6 \text { ADC channels } \\
6 \text { PC channels }\end{array}$ \\
\hline $\begin{array}{l}\text { Range } \\
\text { sampling }\end{array}$ & $3.75 \mathrm{~m}$ & $7.5 \mathrm{~m}$ & $3.75 \mathrm{~m}$ & $7.5 \mathrm{~m}$ & $15 \mathrm{~m}$ \\
\hline $\begin{array}{l}\text { Temporal } \\
\text { sampling }\end{array}$ & $1 \mathrm{~min}$ & $20 \mathrm{~s}$ & $5 \mathrm{~min}$ & $1 \mathrm{~s}$ & $220 \mathrm{~s}$ \\
\hline $\begin{array}{l}\text { Instrument } \\
\text { elevation }\end{array}$ & $2270 \mathrm{~m}$ & $2270 \mathrm{~m}$ & $2285 \mathrm{~m}$ & $2285 \mathrm{~m}$ & $2285 \mathrm{~m}$ \\
\hline $\begin{array}{l}\text { Distance from } \\
\text { TMF } \\
\begin{array}{l}\text { ozonesonde } \\
\text { launch location }\end{array}\end{array}$ & $300 \mathrm{~m}$ & $300 \mathrm{~m}$ & $10 \mathrm{~m}$ & $10 \mathrm{~m}$ & $15 \mathrm{~m}$ \\
\hline
\end{tabular}

above. The data collection system accumulates signals over $1 \mathrm{~s}$ intervals and records the raw data to disk, while a separate processor carries out computation of the ozone and aerosol profiles at the completion of each scanner sequence (typically $5-8 \mathrm{~min}$ ).

\subsection{The NASA-GSFC TROPOZ lidar}

The NASA Goddard Space Flight Center TROPospheric OZone Differential Absorption Lidar (TROPOZ) was designed in 2013 and installed in a $13 \mathrm{~m}$ transportable trailer (Sullivan et al., 2014). It has been routinely taking measurements in the Baltimore-Washington, D.C. region since fall of 2013. Its configuration is similar to the JPL TMTOL lidar. A quadrupled Nd:YAG laser transmits $266 \mathrm{~nm}$ at $50 \mathrm{~Hz}$ into two $1.8 \mathrm{~m}$ long cells filled with deuterium and hydrogen to Raman-shift the $266 \mathrm{~nm}$ wavelength to 289 and $299 \mathrm{~nm}$.

The receiver comprises a $45 \mathrm{~cm}$ diameter Newtonian telescope, four $2.5 \mathrm{~cm}$ refracting telescopes, a set of beam splitters, 289 and $299 \mathrm{~nm}$ interference filters, neutral density filters, and PMTs and allows all altitudes between $400 \mathrm{~m}$ above ground and $12 \mathrm{~km}$ to be covered. Signals from the PMTs are sampled at $50 \mathrm{~ns}$ intervals $(7.5 \mathrm{~m})$ by transient recorders operating in analog and photon-counting modes, and the data are typically recorded every $1 \mathrm{~min}$.

Since its inception, TROPOZ has been deployed to several field campaigns, including NASA's 2014 DISCOVERAQ campaign (Sullivan et al., 2016) and the international KORUS-AQ campaign (Korea-US Air Quality) in 2016 (Sullivan et al., 2017).

\section{Review of the SCOOP campaign schedule and logistics}

\subsection{Lidar instrument deployment}

As mentioned earlier, the planning of the SCOOP campaign leveraged from a favorable field deployment calendar of two of the four mobile TOLNet lidars. In early August 2016, the GSFC-based TROPOZ lidar was in transit back from the KORUS-AQ campaign in South Korea, and the NOAABoulder-based TOPAZ lidar was in transit back from the CABOTS campaign in the California Central Valley (Langford et al., submitted, 2018). The other two mobile lidars, AMOLITE and LMOL, were brought from their respective home bases, i.e., Ontario, Canada, and Hampton, VA, respectively. All lidar systems were ready and operational for the official kickoff of the campaign on 11 August 2016 (UT). The campaign was expected to finish on 17 August (UT), but a local wildfire triggered a 1-day premature end to the campaign due to the mandatory evacuation of TMF. The SCOOP campaign therefore officially ended on 16 August 2016 at 23:00 UT.

In order to optimize the measurements' simultaneity and co-location, two mobile lidars (TOPAZ and TROPOZ) were deployed at the TMF core facility ( $2285 \mathrm{~m}$ a.s.l.) next to the JPL lidar building TM-21 (where TMTOL operates), and the other two mobile lidars (AMOLITE and LMOL) were deployed at the TM-2 Facility ( $2270 \mathrm{~m}$ a.s.1.), an annex to TMF located approximately $400 \mathrm{~m}$ east-southeast of TM21. This deployment configuration allowed the LMOL and AMOLITE lidars to operate next to each other (distance of $20 \mathrm{~m}$ between the two systems) without cross-talk, and allowed LMOL to operate simultaneously with TOPAZ without cross-talk despite similar wavelengths. At the TM-21 location, the TOPAZ system operating at the highest frequency 
$(1000 \mathrm{~Hz})$ provided a master trigger to the TROPOZ $(50 \mathrm{~Hz})$ and TMTOL $(30 \mathrm{~Hz})$ systems, allowing full synchronization and simultaneous operations of the three systems without cross-talk. Although cross-talk was avoided, spurious electronic interference in the TROPOZ and TMTOL signals occasionally occurred, partly due to a defective grounding of a TOPAZ subsystem and partly due to the poor quality and extended length of trigger cables feeding TMTOL for the occasion. These complications caused the TOPAZ and TMTOL systems to miss a few hours of measurement and a couple of ozonesonde launches.

\subsection{Lidar operation schedule}

The operational schedule of the SCOOP campaign was designed to spread the lidar measurements over all times of the day and night, over the course of 1 week. The AMOLITE lidar is automated and acquired measurements nearly $24 \mathrm{~h}$ a day, 7 days a week. The other four lidars followed a predefined incremental measurement schedule, with more hours each day as the campaign progressed:

- 10-11 August (UT): 2 h, early night;

- 11-12 August (UT): $6 \mathrm{~h}$ spread from midday to evening/early night;

- 12-13 August (UT): $8 \mathrm{~h}$ spread from late night/early morning to midday;

- 13-14 August (UT): $12 \mathrm{~h}$ spread from midday to midnight;

- 14-15 August (UT): rest day;

- 15-16 August (UT): $18 \mathrm{~h}$ spread from late night/early morning to evening/early night;

- 16-17 August (UT): $24 \mathrm{~h}$ spread from midday to midday next day (truncated by evacuation).

The above schedule defined the minimum requirement of SCOOP coordinated measurements. Most lidar instruments actually operated beyond the minimum requirement, leading to several hundreds of accumulated hours. Table 3 summarizes the operating times of all lidars over the SCOOP campaign period.

\subsection{Other instrument operations during SCOOP}

The JPL-TMF lidar group manages the operation of several balloon systems at TMF. In support of the SCOOP campaign, 17 electrochemical concentration cell (ECC) ozonesondes (Komhyr, 1969; Smit et al., 2007) were launched from the site between 10 and 17 August. Another ozonesonde was launched 3 days prior to the official start of the campaign as a pre-campaign test flight. The ozonesonde launch times were tailored to match the needs of the SCOOP campaign, with a number of launches ranging from a minimum of one launch per day on 10 and 11 August (UT) to a maximum of six launches (one launch every $2 \mathrm{~h}$ ) on 15 and $16 \mathrm{Au}$ gust (UT). All the lidar measurements and launches planned on 17 August (UT) were canceled due to the mandatory site evacuation order. Figure 1 summarizes the complete campaign schedule, including ozonesonde launches (labeled "ECC") and lidar operating times. In all upcoming figures, the ozonesonde data will be labeled "ECC".

Other in situ or remote-sensing instruments operated during the campaign. An automated surface ozone analyzer (ThermoFisher 49i) has been operating continuously at TMF since 2013. Several similar surface ozone instruments were also deployed as part of the TOLNet mobile lidars' added instrumentation. The surface ozone data are typically used to infer physically meaningful correlation relations between the values measured by lidar at their lowermost boundary (usually $200-600 \mathrm{~m}$ above ground) and the surface.

The JPL-TMF lidar group operates two other lidars at TMF for NDACC. The water vapor Raman lidar (Leblanc et al., 2012) was operated on three nights during SCOOP (10, 12, and 16 August, UT), and the stratospheric ozone lidar just resumed operations during SCOOP after a several-month break due to laser failure. No results from those lidars will be shown in this article, but it is expected that the measurements from these lidars will be used together with the SCOOP campaign results for upcoming science investigations.

\subsection{Table Mountain Facility environmental and meteorological conditions during SCOOP}

The JPL Table Mountain Facility $\left(34.38^{\circ} \mathrm{N}, 117.68^{\circ} \mathrm{W}\right)$ is at the top of a ridge, on the north (Mohave Desert) side of the San Gabriel Mountains, northeast of the Los Angeles Basin in Southern California. It is a high-elevation site ( $2285 \mathrm{~m}$ a.s.l.), above the planetary boundary layer in all seasons except late spring and summer. At the surface, the ozone diurnal cycle is typically similar to that observed in the nearby high desert and is much less pronounced than in the urban, near-sea-level Los Angeles Basin. The high elevation of TMF guarantees clean, clear skies over most of the lidars' measuring range, although in summer the site is embedded in the top $1 \mathrm{~km}$ of the planetary boundary layer. Cloud interference during the SCOOP campaign remained minimal. Out of the 7 campaign days, mid-elevation, afternoon cumulus clouds (altitude: $3-5 \mathrm{~km}$ a.s.l.) appeared on three occasions, on 12 August between 10:00 and 16:00 PDT, 13 August between 10:00 and 18:00 PDT, and 16 August after 13:00 PDT. Scattered high clouds (altitude: 8-12 km a.s.l.) passed over TMF during the night of 11 August (PDT) and in the evening of 13 August (PDT). These favorable weather conditions allowed the lidars to measure during more than $90 \%$ of the SCOOP-prescribed coordinated days and times mentioned earlier. 
Table 3. Lidar data availability during SCOOP.

\begin{tabular}{|c|c|c|c|c|c|c|}
\hline $\begin{array}{l}\text { Date } \\
\text { (local time) }\end{array}$ & $\begin{array}{l}\text { Date } \\
\mathrm{UT}^{1}\end{array}$ & $\begin{array}{l}\text { AMOLITE } \\
(\mathrm{UT})^{2}\end{array}$ & $\begin{array}{l}\text { LMOL } \\
(\mathrm{UT})^{2}\end{array}$ & $\begin{array}{l}\text { TMTOL } \\
(\mathrm{UT})^{2}\end{array}$ & $\begin{array}{l}\text { TOPAZ } \\
(\mathrm{UT})^{2}\end{array}$ & $\begin{array}{l}\text { TROPOZ } \\
(\mathrm{UT})^{2}\end{array}$ \\
\hline \multirow[t]{2}{*}{9 August } & 2016/08/09 & $07: 00-23: 59$ & I & I & I & I \\
\hline & $2016 / 08 / 10$ & $00: 00-06: 59$ & $03: 30-05: 55$ & $03: 44-05: 45$ & I & $03: 40-06: 17$ \\
\hline \multirow{2}{*}{10 August } & $2016 / 08 / 10$ & 07:00-23:59 & $18: 45-22: 15$ & 1 & I & I \\
\hline & 2016/08/11 & 00:00-06:59 & 00:00-05:15 & $02: 24-04: 24$ & $04: 44-05: 24$ & $02: 33-04: 28$ \\
\hline \multirow[t]{2}{*}{11 August } & $2016 / 08 / 11$ & 07:00-23:59 & $18: 30-21: 45$ & $19: 03-21: 39$ & 19:19-23:59 & $19: 57-21: 39$ \\
\hline & $2016 / 08 / 12$ & 00:00-06:59 & $00: 00-01: 35$ & $00: 04-04: 21$ & 00:00-02:39 & $00: 00-03: 15$ \\
\hline \multirow[t]{2}{*}{12 August } & $2016 / 08 / 12$ & 07:00-18:08 & $11: 10-18: 40$ & $11: 00-19: 15$ & $10: 55-19: 15$ & 11:07-19:09 \\
\hline & $2016 / 08 / 13$ & $01: 24-06: 59$ & I & I & l & l \\
\hline \multirow[t]{2}{*}{13 August } & $2016 / 08 / 13$ & $07: 00-23: 59$ & $18: 45-23: 59$ & $17: 58-23: 59$ & $18: 18-23: 59$ & $18: 57-23: 59$ \\
\hline & $2016 / 08 / 14$ & 00:00-06:59 & 00:00-05:00 & $00: 01-02: 41$ & 00:00-05:08 & $00: 00-05: 47$ \\
\hline \multirow[t]{2}{*}{14 August } & $2016 / 08 / 14$ & 07:00-23:59 & I & 1 & I & I \\
\hline & $2016 / 08 / 15$ & 00:00-06:59 & & & & \\
\hline \multirow[t]{2}{*}{15 August } & $2016 / 08 / 15$ & 07:00-23:59 & 11:00-23:59 & $10: 36-23: 59$ & $10: 15-23: 59$ & $10: 59-23: 59$ \\
\hline & $2016 / 08 / 16$ & 00:00-06:59 & 00:00-06:00 & $00: 27-06: 42$ & $00: 00-05: 35$ & $00: 00-05: 13$ \\
\hline \multirow[t]{2}{*}{16 August } & $2016 / 08 / 16$ & $07: 00-23: 59$ & $19: 30-21: 55$ & $20: 49-22: 41$ & $19: 28-22: 48$ & $21: 03-22: 40$ \\
\hline & $2016 / 08 / 17$ & $00: 00-06: 59$ & I & l & I & / \\
\hline Total & 7 days & $\geq 200 \mathrm{~h}$ & $52 \mathrm{~h}$ & $49 \mathrm{~h}$ & $48 \mathrm{~h}$ & $47 \mathrm{~h}$ \\
\hline
\end{tabular}

${ }^{1}$ Change of UT date occurs at 17:00 LT (PDT). ${ }^{2}$ Start and end times.

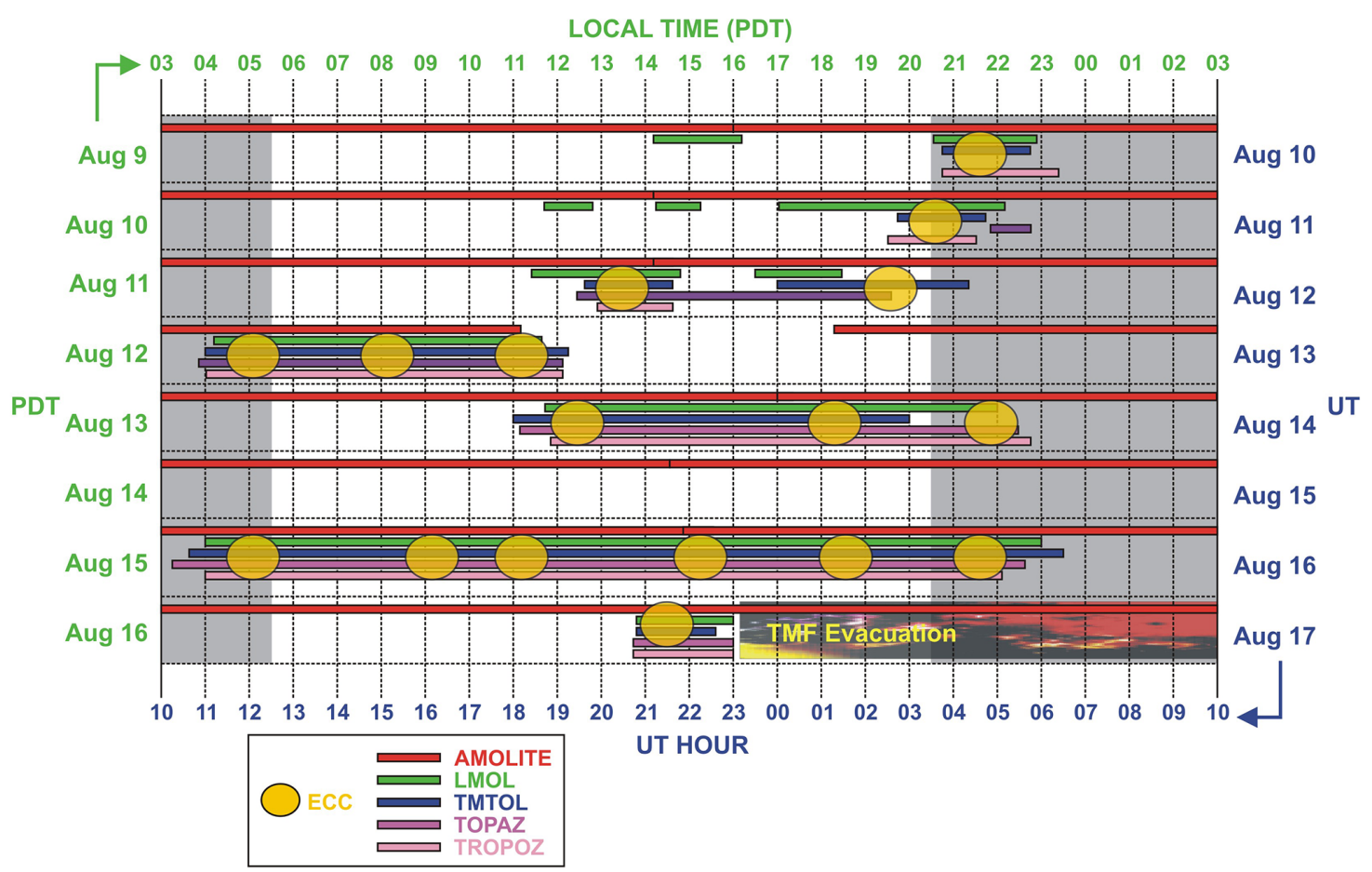

Figure 1. SCOOP campaign operation schedule for the five participating TOLNet lidars and 17 ECC ozonesonde launches. Grey-shaded areas denote nighttime. 
An example of a $20 \mathrm{~h}$ long measurement run by the JPL lidar TMTOL is shown in Fig. 2. This ozone curtain plot, obtained on 14 August, is typical of what all five co-located lidars have been measuring day after day during the campaign (a 31-day-long streak by AMOLITE is shown at the end of this article). The lidar's maximum vertical range is limited to $8 \mathrm{~km}$ in the middle of the day (08:00 to 11:00 UT) but extends to $14-16 \mathrm{~km}$ at nighttime for the $10 \mathrm{~min}$ profiles shown here. Ozone measured by six ozonesondes launched on that day is superimposed in the form of colored rectangles. In most cases, they are barely noticeable because of the excellent quantitative agreement between lidar and ozonesonde. On this particular day, a clear layer of high ozone mixing ratio (80-90 ppbv) is observed between 4 and $7 \mathrm{~km}$, reaching the ground in the evening. Figure 2 also highlights the high ozone temporal variability, observed, for example, between 00:00 and 06:00 UT on 15 August near 6-7 km a.s.l. (ozone increase from 40 to $80 \mathrm{ppbv}$ ). High geophysical variability cannot be ignored when comparing non-simultaneous measurements (e.g., Vogelmann et al., 2011), and particular care, not only on co-location but also simultaneity, must be taken.

\subsection{SCOOP Level 2 data: 30 min coincident lidar-ozonesonde profiles}

Hundreds of hours of lidar measurements were carried out during SCOOP. However, in order to minimize biases due to geophysical variability (see previous paragraph), only simultaneous profiles were critically compared. Therefore, the results presented hereafter focus on the lidar measurements made simultaneously with the first $30 \mathrm{~min}$ of each SCOOP ozonesonde flight (i.e., the tropospheric part of the flights). Furthermore, during the blind validation phase ("blind" refers to ozone profiles retrieved by the five lidar teams without prior knowledge of the ozonesonde and other lidars' profiles), all five TOLNet lidar groups were asked to produce ozone profiles with the same effective vertical resolution in order to minimize biases introduced by differing vertical smoothing applied to the raw lidar data. The $30 \mathrm{~min}$ averaged sonde-coincident lidar profiles with this prescribed SCOOP effective vertical resolution scheme will be referred to as "SCOOP Level 2" data throughout the rest of this work. The prescribed SCOOP effective vertical resolution scheme is altitude-dependent, linearly increasing from $200 \mathrm{~m}$ at altitude of $2.7 \mathrm{~km}$ a.s.1. to $1500 \mathrm{~m}$ at altitude of $8.1 \mathrm{~km}$ a.s.1, and then fixed to $1500 \mathrm{~m}$ above that. The vertical resolution scheme is shown in Fig. 3a. Quantitatively, this scheme was chosen to ensure that random noise in the ozone profiles from all five lidars remains small. It is conservative for the LMOL, AMOLITE, and TOPAZ lidars, which could have benefited from a higher vertical resolution, but it provides just enough smoothing for the TMTOL low-intensity channels to avoid the presence of excessive random noise. Vertical smoothing was also applied to the ozonesonde profiles to mimic the SCOOP effective vertical resolution scheme used for the li- dars. By default, the ozonesonde raw data are produced at $1 \mathrm{~s}$ (approx. $5 \mathrm{~m}$ ) intervals, but their effective vertical resolution is $100-120 \mathrm{~m}$ due to the sonde time response of about $20 \mathrm{~s}$ (WMO, 2014). To account for the difference between the lidar's typical vertical sampling resolution of a few meters and the 100-120 m vertical resolution of the sonde, the averaging kernels applied to the sonde profiles to mimic the lidar's effective resolution are slightly different from those applied to the raw lidar signals. What counts in the end is not the averaging kernels themselves but how these kernels translate in terms of effective resolution. The middle and right panels of Fig. 3 show a comparison of ozonesonde profiles at the raw vertical resolution and at the SCOOP vertical resolution. Differences of $20 \mathrm{ppb}$ or more can be found for individual flights. When averaging profiles from all 17 SCOOP launches, the differences reach up to $5 \mathrm{ppbv}(10 \%)$ at $9 \mathrm{~km}$ and above (not shown). Working with the same effective vertical resolution for all lidars and all ozonesonde profiles therefore avoids the introduction of smoothing-induced differences of up to $5 \mathrm{ppbv}$, or $10 \%$, in the SCOOP Level 2 mean profile comparisons shown thereafter.

Because of the operational constraints of the lidars, not all instruments were fully operational during each SCOOP ozonesonde flight. Furthermore, mid-elevation clouds appeared during 4 of the 17 ozonesonde flights, impacting differently the ozone retrievals of the various lidars. As a result, the actual number of ozonesonde-lidar coincidences is not 17 for all systems, and the list of launches used for the comparisons varies from one pair of instruments to another. Table 4 summarizes the coincidences used, instrument by instrument, to produce the SCOOP Level 2 data after operational and weather constraints were taken into account. Figure 4 illustrates the sampling bias issues caused by the coincidence heterogeneity. For each of the six panels (ozonesonde +5 lidars), the flight numbers during which valid ozone measurements were made are listed (different color for each flight). From this figure and as anticipated from the high temporal variability observed in Fig. 2, it is clear that the mean ozone profiles computed using one-to-one instrument coincidences are expected to vary significantly. This is confirmed in Fig. 5, which shows the mean ozone profiles computed for AMOLITE (left panel) and LMOL (right panel) when measurements coincide with the other instruments. For example, the mean AMOLITE ozone profile computed using all coincidences with TMTOL (blue curve) is significantly different from the mean AMOLITE ozone profile computed using all coincidences with TOPAZ (purple curve). To minimize the impact of this heterogeneity (and the underlying differences therefore introduced by geophysical variability), the differences between ozonesonde and lidar were investigated in a statistical manner, using the ozonesonde as the reference transfer. This approach maximizes the number of coincidences between the ozonesondes and one given lidar but prevents us from comparing all sondes and all lidars together simultaneously. This approach also minimizes the im- 


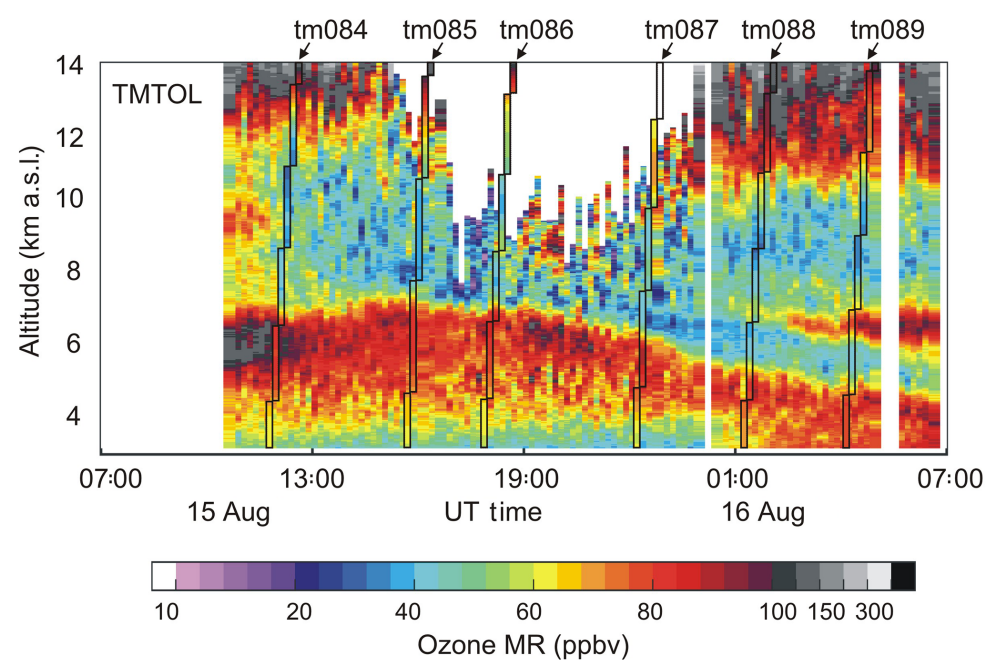

Figure 2. Ozone time-altitude cross section obtained by the JPL TMTOL lidar on 14 August 2016 (time resolution: 10 min). Ozone measured by the six ozonesondes launched on that day is superimposed using thin, colored, slanted rectangles.
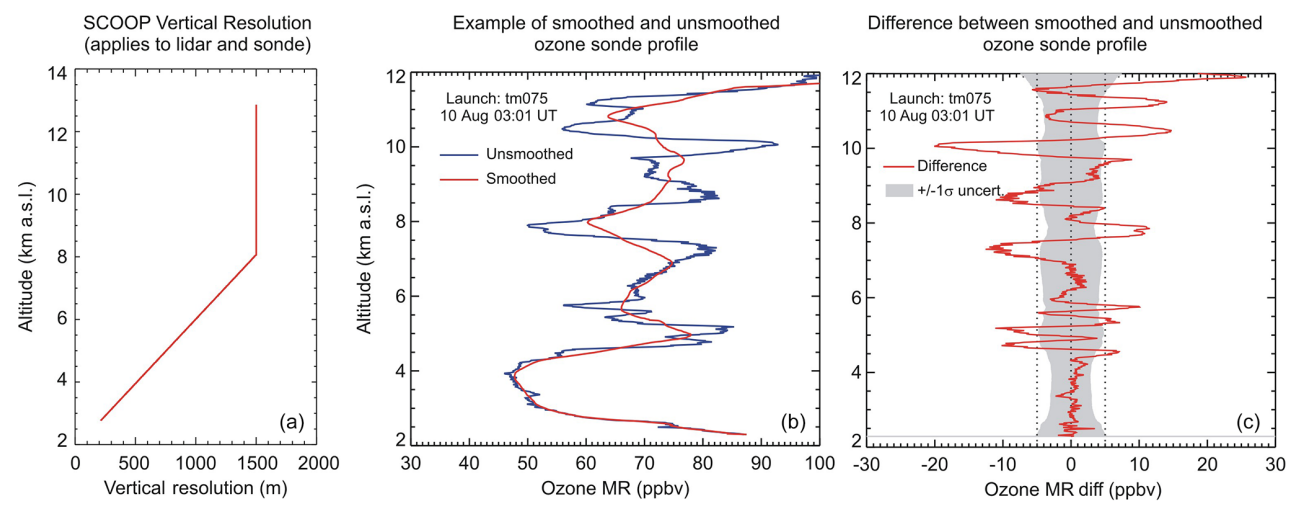

Figure 3. (a) Effective vertical resolution scheme used for all lidars and ozonesonde profiles for the blind validation phase of SCOOP (referred to as "SCOOP Level 2" data; see text for details). (b) Example of ozonesonde profile before (blue) and after (red) the SCOOP vertical resolution scheme is applied. (c) Difference between smooth and unsmoothed ozonesonde profiles shown in (b). Grey-shaded area points out \pm 1 standard uncertainty.

pact of residual noise associated with changes in the number of samples used for the comparisons.

SCOOP Level 2 data validation results are presented thereafter. As part of the overall TOLNet lidar validation efforts, both the measurements and the retrieval algorithms were actually validated. This twofold approach allows, in theory, the separation of biases due exclusively to the experimental conditions and those due exclusively to the data processing algorithms. The next section focuses on the algorithm aspects.

\section{Standardization and validation of the TOLNet lidar data processing algorithms}

As part of producing the best-quality and most homogeneous ozone profile dataset possible, the TOLNet community has engaged in a large effort to standardize and validate all TOL-
Net in-house data processing algorithms. This process leveraged from similar work done within the NDACC lidar community a few years ago (Leblanc et al., 2016a, b) and led to the full implementation of several standardized features within the TOLNet algorithms today.

\subsection{Use of simulated lidar signals and centralized data processing to validate the algorithms}

Each standardized feature of the algorithms was verified through a comprehensive algorithm validation exercise. The modus operandi of this exercise is as follows: (1) consider "known" atmospheric conditions (density, temperature, ozone, and other chemical species), (2) simulate raw lidar signals under these conditions by a specific TOLNet lidar (forward model), (3) analyze the simulated signals using the TOLNet lidar in-house data processing algorithm to be vali- 

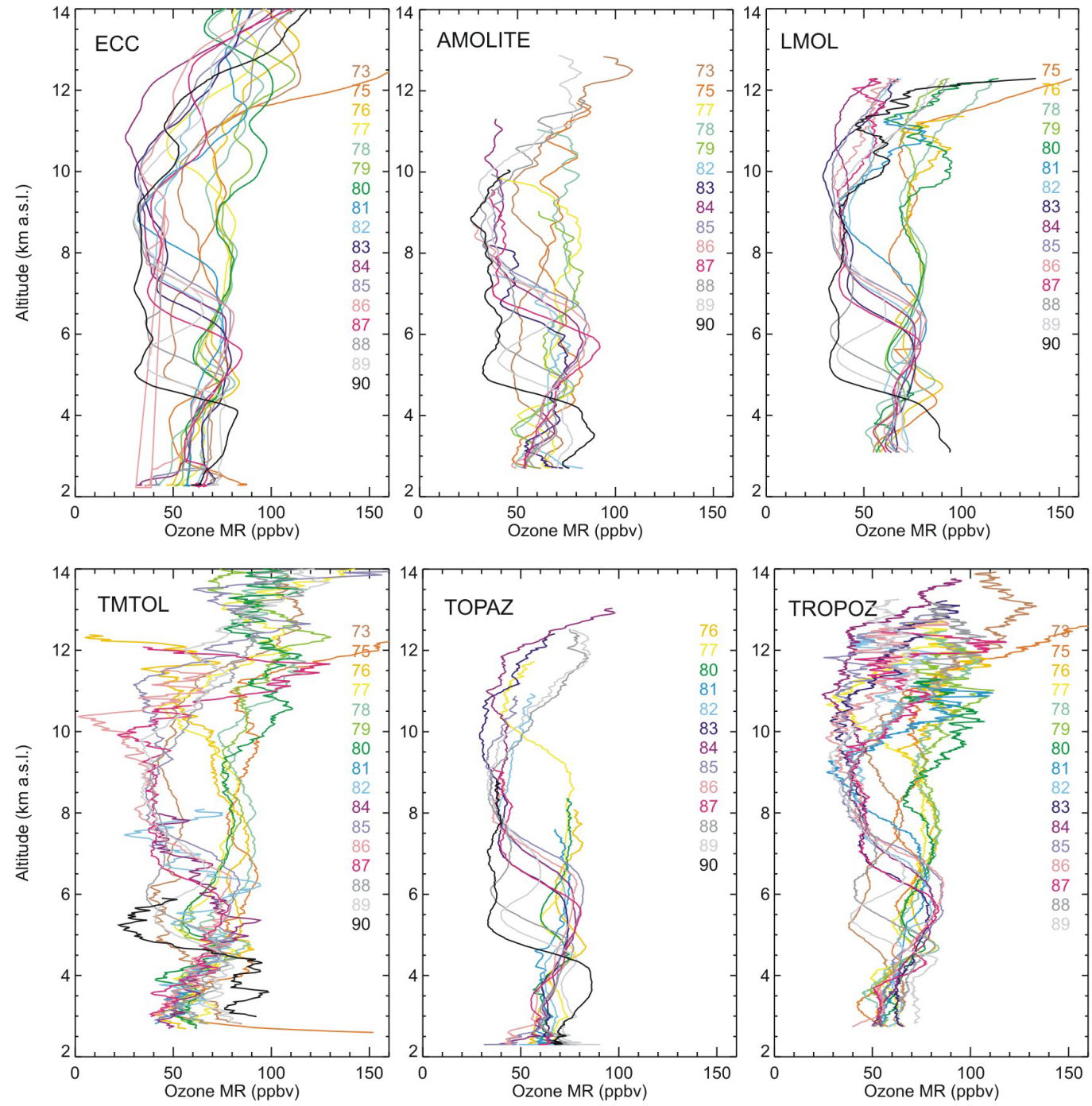

Figure 4. Top-left panel: ECC ozonesonde profiles measured during each of the 17 launches performed during the SCOOP campaign (launch numbers listed on the side). All other panels: ozone profiles measured by lidar during each available coincident sonde-lidar measurements. Coincidences (number and list) vary by instrument.

dated (inverse model), and (4) compare the ozone profile retrieved by the in-house data processing algorithm with the original ozone profile used to simulate the signals. If the retrieved and original profiles differ significantly, the source of the difference is investigated, corrections to the algorithm are made wherever necessary, and steps 3 and 4 above are repeated until both original and retrieved profiles match perfectly (except for very small differences due to numerical rounding errors). This approach is used to validate not only the retrieved ozone profiles but also other products output by the algorithms, for example, vertical resolution and uncertainty.

An example of algorithm validation results, in the context of SCOOP, is provided in Fig. 6. The left panel of this figure shows a comparison between the original ozone profile used in the forward model (cyan curve) and the profile retrieved by the AMOLITE in-house data processor (red curve). In this example, the forward model used the atmospheric conditions $\left(T, p, \mathrm{O}_{3}\right)$ of the SCOOP ozonesonde tm073 launched on 10 August 2016. The original profile is barely noticeable because the agreement is excellent and the retrieved profile is just on top of it. The purpose of this particular simulation run was to validate the AMOLITE in-house retrieval in absence of smoothing, and therefore the raw lidar signals were simulated without detection noise. The increasing noise at the top of the red profile is not detection noise but simply the result of rounding errors associated with the numerical digitization of the simulated raw lidar signals. The middle panel shows the difference (in percent) between the AMOLITE inhouse-retrieved ozone profile and the original ozone profile. 
Table 4. Ozonesonde and 30 min lidar coincidences used to obtain the SCOOP Level 2 data.

\begin{tabular}{|c|c|c|c|c|c|c|}
\hline $\begin{array}{l}\text { Ozonesonde } \\
\text { Date/time (UT) }\end{array}$ & $\begin{array}{l}\text { Ozonesonde } \\
\text { name }\end{array}$ & $\begin{array}{l}\text { AMOLITE } \\
\text { (UT) }\end{array}$ & $\begin{array}{l}\text { LMOL } \\
\text { (UT) }\end{array}$ & $\begin{array}{l}\text { TMTOL } \\
\text { (UT) }\end{array}$ & $\begin{array}{l}\text { TOPAZ } \\
\text { (UT) }\end{array}$ & $\begin{array}{l}\text { TROPOZ } \\
\text { (UT) }\end{array}$ \\
\hline 2016/08/10, 04:01 & $\operatorname{tm} 073$ & 04:01-04:31 & l & $04: 05-04: 35$ & l & 04:01-04:32 \\
\hline 2016/08/11, 03:01 & $\operatorname{tm} 075$ & 03:01-03:31 & 03:00-03:30 & 03:04-03:34 & $04: 40-05: 10$ & $03: 01-03: 32$ \\
\hline 2016/08/11, 20:01 & $\operatorname{tm} 076$ & l & 20:00-20:30 & $20: 00-20: 27$ & 20:01-20:31 & 20:01-20:31 \\
\hline 2016/08/12, 02:01 & $\operatorname{tm} 077$ & 02:01-02:31 & $01: 30-02: 00$ & 02:00-02:34 & $02: 01-02: 31$ & $02: 01-02: 32$ \\
\hline 2016/08/12, 11:32 & $\operatorname{tm} 078$ & $11: 32-12: 02$ & $11: 30-12: 00$ & $11: 34-12: 04$ & $11: 21-11: 47$ & 11:31-12:02 \\
\hline 2016/08/12, 14:39 & $\operatorname{tm} 079$ & $14: 39-15: 09$ & $14: 39-15: 09$ & $14: 39-15: 08$ & $14: 13-14: 43$ & 14:39-15:09 \\
\hline $2016 / 08 / 12,17: 33$ & $\operatorname{tm} 080$ & / & $17: 38-18: 08$ & $17: 35-18: 05$ & $17: 33-18: 03$ & 17:33-18:04 \\
\hline 2016/08/13, 19:01 & $\operatorname{tm} 081$ & l & 19:00-19:30 & $19: 03-19: 32$ & 19:01-19:31 & 19:01-19:31 \\
\hline 2016/08/14, 00:44 & $\operatorname{tm} 082$ & $00: 44-01: 14$ & $00: 40-01: 10$ & $00: 47-01: 17$ & $00: 44-01: 14$ & $00: 43-01: 14$ \\
\hline 2016/08/14, 04:15 & $\operatorname{tm} 083$ & $04: 15-04: 45$ & $04: 15-04: 45$ & I & $04: 15-04: 45$ & $04: 15-04: 45$ \\
\hline 2016/08/15, 11:37 & $\operatorname{tm} 084$ & $11: 37-12: 07$ & $11: 35-12: 05$ & 11:37-12:09 & $11: 37-12: 07$ & 11:36-12:07 \\
\hline 2016/08/15, 15:32 & $\operatorname{tm} 085$ & $15: 32-16: 02$ & $15: 30-16: 00$ & $15: 33-16: 03$ & $15: 32-16: 02$ & $15: 31-16: 02$ \\
\hline $2016 / 08 / 15,17: 42$ & tm086 & $17: 42-18: 12$ & $17: 40-18: 10$ & $17: 45-18: 15$ & $17: 42-18: 12$ & $17: 41-18: 10$ \\
\hline 2016/08/15, 21:47 & $\operatorname{tm} 087$ & $21: 53-22: 23$ & $21: 45-22: 15$ & $21: 50-22: 20$ & $21: 47-22: 17$ & $21: 46-22: 17$ \\
\hline 2016/08/16, 01:02 & $\operatorname{tm} 088$ & 01:02-01:32 & 01:00-01:30 & 01:03-01:33 & 01:02-01:32 & 01:01-01:32 \\
\hline 2016/08/16, 03:59 & $\operatorname{tm} 089$ & 03:59-04:29 & 03:59-04:29 & $04: 05-04: 34$ & 03:59-04:29 & $03: 58-04: 28$ \\
\hline 2016/08/16, 21:03 & tm090 & $21: 03-21: 33$ & $21: 00-21: 30$ & $21: 03-21: 33$ & $21: 03-21: 33$ & $21: 21-21: 52$ \\
\hline
\end{tabular}
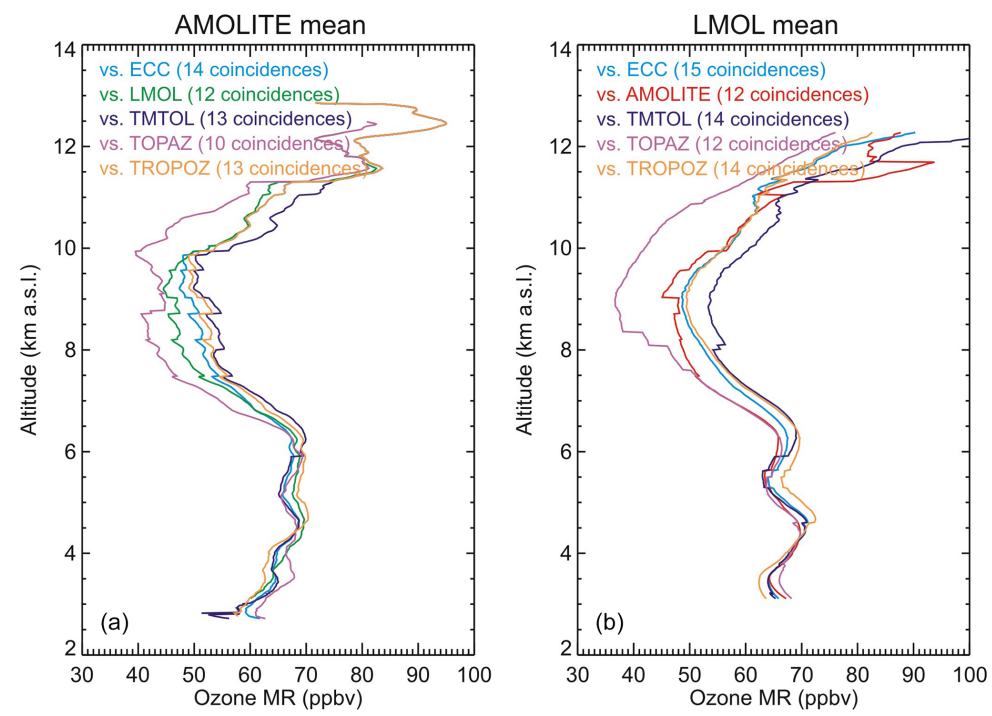

Figure 5. Mean AMOLITE (a) and LMOL (b) ozone profiles computed using one-on-one coincidences with each of the other instruments.

These results show that the AMOLITE in-house data processing algorithm produces the correct profile (i.e., no bias), keeping in mind that the numerical rounding errors at the top are an artifact that does not exist with real measurements. As part of the complete validation process, the ozone profile retrieved by the AMOLITE in-house data processor was also compared to the ozone profile retrieved by the centralized data processing software GLASS (Global Lidar Analysis Software Suite) developed at JPL-TMF. The GLASS includes all the standardization features recommended within NDACC and prescribed for the TOLNet data processing algorithms (Leblanc, 2019, manuscript in preparation). It can therefore be used here as a reference transfer. The difference between the AMOLITE in-house and GLASS retrievals is shown in the right panel of Fig. 6 (green curve). Because the numerical rounding errors were propagated similarly through both the GLASS and the AMOLITE in-house data processor, a better agreement and reduced noise are found between the two retrieved ozone profiles, compared to the difference observed with the original profile.

As part of the TOLNet-wide algorithm validation efforts, simulation runs similar to the present example were performed for all TOLNet instruments, either before or after SCOOP (e.g., Sullivan et al., 2015). This comprehensive ef- 


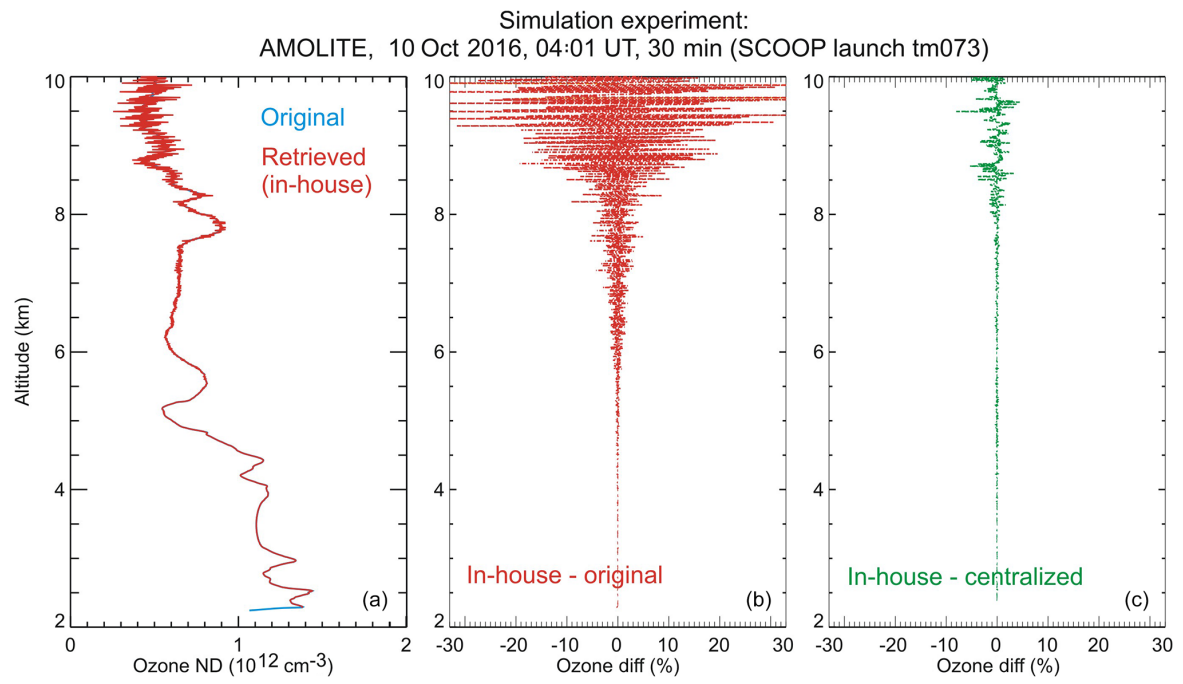

Figure 6. Example of algorithm validation result (see text for details). (a) Ozone profile used in the algorithm validation forward model (cyan curve), and ozone profile retrieved by the AMOLITE in-house data processing (red curve) using the simulated lidar signals produced by the forward model. (b) Difference (\%) between the retrieved and original ozone profiles shown in the left panel. (c) Difference between the AMOLITE-retrieved and GLASS-retrieved profiles (see text for details).
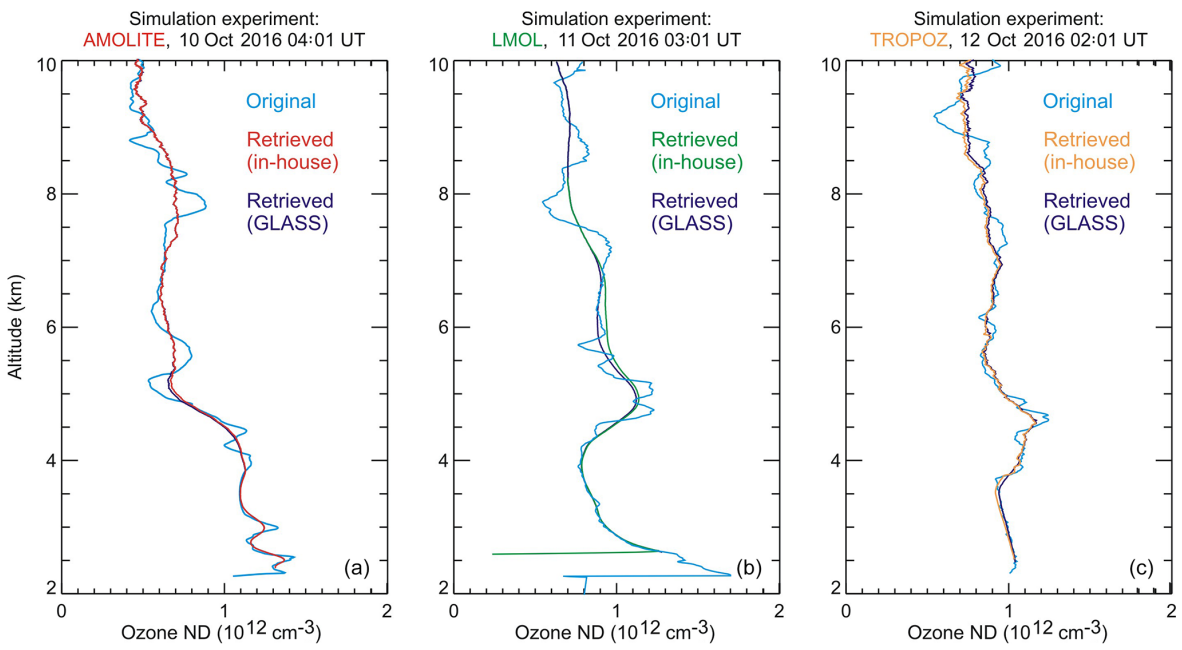

Figure 7. Another example of algorithm validation result, this time testing vertical resolution (see text for details). (a) Ozone profile used in the forward model (cyan curve), and ozone profile retrieved by the AMOLITE in-house data processing (red curve) and GLASS (blue curve), both at the same prescribed SCOOP vertical resolution. (b, c) Same as left panel but for LMOL and TROPOZ, respectively.

fort led to the full validation of the TOLNet in-house retrievals, and any ozone bias identified during SCOOP between sonde and lidar, or between lidar and lidar, should not be expected to originate from the data processing algorithms.

\subsection{Standardized effective vertical resolution}

In addition to the retrieved ozone profiles, an essential algorithm feature to validate is effective vertical resolution. The standardized definition used by all TOLNet lidar groups is the NDACC-standardized definition prescribed in Leblanc et al. (2016a). Using this definition, the reported vertical reso- lution corresponds to the FWHM of the response to a finite impulse, namely, a delta function for smoothing filters and a Heaviside step function for derivative filters. In DIAL retrievals, vertical smoothing can be applied either to the raw lidar signals or to the retrieved ozone profiles, or to both, by using either smoothing filters or derivative filters - hence the importance of using a standardized definition that is representative of a specific effective resolution. A validation example is provided in Fig. 7. The left panel shows the original simulated ozone profile used in the forward model (cyan curve), and the AMOLITE in-house-retrieved and GLASS- 
retrieved ozone profiles (red and blue curve, respectively). The simulated ozone profile is the same as in Fig. 6; i.e., it is taken from the SCOOP launch tm073 on 10 August 2016. Both in-house- and GLASS-retrieved profiles are smoother than the original profile as they were both processed using the same SCOOP effective vertical resolution scheme introduced in Sect. 3.5. The excellent agreement between the two retrieved profiles confirms that the AMOLITE in-house data processor applies the correct amount of smoothing, i.e., that it uses the correct definition of effective vertical resolution. The middle and right panels are similar to the left panel but for LMOL and TROPOZ. They are additional examples illustrating that the other TOLNet data processing algorithms were checked for computing a consistent effective vertical resolution.

\subsection{Standardized uncertainty budget}

The next major aspect of the TOLNet algorithms that was standardized and validated is the uncertainty budget. The AMOLITE, LMOL, TMTOL, and TROPOZ data processing algorithms were checked to ensure that their uncertainty budget followed the NDACC recommendations on uncertainty provided in Leblanc et al. (2016b). No such check occurred for TOPAZ as no uncertainty estimates were provided with their SCOOP Level 2 data. Figure 8 shows an example of the detailed uncertainty budget computed by the AMOLITE (top left), LMOL (top right), TMTOL (bottom left), and TROPOZ (bottom right) in-house algorithms (solid curves) compared to their equivalent computed by the GLASS (thick dash curves, similar hues). The uncertainty budget computed by the GLASS follows the NDACC recommendations and can be used once again as a reference transfer. The random component of total uncertainty comes essentially from detection noise (Poisson statistics). This term is represented in black/grey in Fig. 8. The ozone total systematic uncertainty component is a combination of propagated ozone absorption cross-section differential uncertainty (pink/purple), signal (PMT) saturation correction uncertainty (yellow/orange), background noise (skylight) correction uncertainty (blue/cyan), Rayleigh scattering cross-section uncertainty (green), and air density uncertainty (brown). Aerosol extinction and backscatter uncertainty is not included in the present uncertainty budget, partly because its quantitative estimation is difficult and no standardized recommendation exists, and partly because the SCOOP campaign took place at Table Mountain Facility, a high-elevation site, i.e., mostly above the boundary layer, with reduced impact from aerosols considering the wavelength differentials considered (Trick et al., 2015). The ozone total uncertainty is the quadratic sum of all uncertainty components shown in Fig. 8. In this figure, the effect of transitioning between channels (ranges) of different intensity (near field to far field, low intensity to high intensity, analog to photon counting, etc.) is manifested by sharp or step-like vertical gradients of uncertainty.

When comparing the solid and dash curves of similar hue in Fig. 8, it is clear that all four in-house data processing algorithms (solid curves) follow closely the GLASS computation (dash curves). Note that for TMTOL the in-house and GLASS computations are identical, so the solid and dash curves overlap perfectly. There are only two cases of disagreement, both of which can easily be explained. One case is the saturation correction uncertainty (yellow) for AMOLITE near $5 \mathrm{~km}$ and TROPOZ near $6 \mathrm{~km}$. The discrepancy is simply due to the fact that the GLASS algorithm does not combine the low- and high-intensity channels in the same way the AMOLITE and TROPOZ in-house algorithms do. The other case of disagreement is for random uncertainty (black/grey curves) below $5 \mathrm{~km}$ for AMOLITE and below $4 \mathrm{~km}$ for TROPOZ. This is due to the fact that the GLASS does not compute random uncertainty for analog channels the same way the AMOLITE and TROPOZ in-house data processors do. This result calls for further work needed on possible recommendations to standardize this particular aspect of the data processing, not only for random uncertainty but for all components of uncertainty for analog signals.

Figure 8 also provides important insights on the relative magnitude of each uncertainty component contributing to the total uncertainty, as a function of altitude, and depending on the instrument considered. For example, the ozone uncertainty owing to the absorption cross-section differential uncertainty (pink/purple curves) has a consistent behavior across all instruments, with nearly constant values of $2 \%$ (AMOLITE, TMTOL, and TROPOZ) and $4 \%$ (LMOL) throughout the entire profile. As part of the algorithm standardization process, a common set of temperatureand wavelength-dependent ozone absorption cross sections, and their uncertainty, was used. This dataset originates from the works of Daumont et al. (1992) and Malicet et al. (1995) for the absorption cross section values, and from Weber et al. (2016) for their uncertainty. The original dataset is interpolated every $0.01 \mathrm{~nm}$ between $260 \mathrm{~nm}$ and $320 \mathrm{~nm}$, and every $0.1 \mathrm{~K}$ from 160 to $330 \mathrm{~K}$, and then written in a unique lookup table file to be read by the TOLNet data processing algorithms, leading to typical uncertainties of $2 \%-4 \%$, depending on temperature considered (e.g., Weber et al., 2016; Viallon et al., 2015).

Similarly to absorption cross-section differential uncertainty, the ozone uncertainty components owing to molecular extinction correction uncertainty (green and brown curves) exhibit a consistent altitude dependence and magnitude for all instruments. This is explained by the consistent use by all TOLNet lidar data processing algorithms of the same source of ancillary temperature and density profiles (and their uncertainty) during SCOOP. In the case of the SCOOP Level 2 data, the temperature and pressure measurements from the InterMet PTU radiosondes coupled with the ozonesondes were used. 

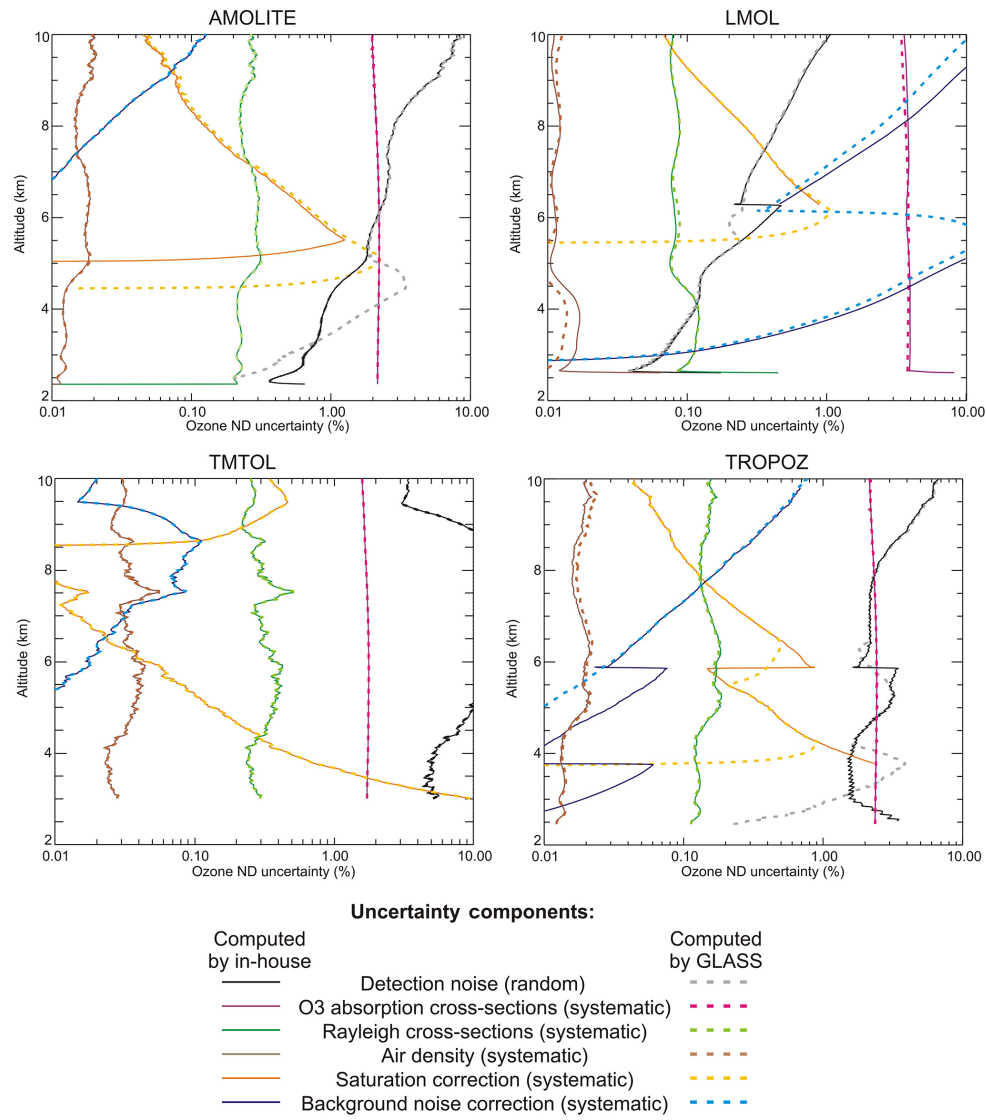

Figure 8. NDACC-standardized ozone uncertainty budget for four of the five TOLNet lidars participating in SCOOP, including one random component (black: detection noise) and five systematic components (pink: ozone absorption cross sections; green: Rayleigh cross-sections; blue: background noise correction; brown: air density; yellow: saturation correction). Solid curves denote ozone uncertainty (\%) computed by the in-house data processing algorithms, while dash curves denote the ozone uncertainty computed by the GLASS (reference transfer).

On the other hand, no obvious consistency is observed for the remaining ozone uncertainty components, namely the components owing to detection noise (black/grey curves), saturation correction (yellow/orange), and background noise correction (blue/cyan). These components are indeed instrument-dependent and show large differences, both in magnitude and shape. The different instrument characteristics and the different range combination options show that there is not one simple characterization of uncertainty for the TOLNet ozone lidars, even though they all use a consistent uncertainty budget approach.

\subsection{From data processing algorithm validation to ozone profile validation}

The purpose of the data processing algorithm validation described above is to identify and/or characterize sources of bias that are due not to the measurements or instrument conditions but, instead, to the data processing algorithms. Through a few selected examples, it was shown that the in-house TOLNet data processing algorithms participating in SCOOP were validated. Any deviation observed during SCOOP between sonde and lidar, or between two lidars, that exceeds the differences observed at the conclusion of these algorithm validation efforts (typically $1 \%$ ) should therefore be interpreted as owing to the experimental conditions rather than the algorithms.

Despite the large efforts to standardize and validate the TOLNet data processing algorithms, there are still a few features that were not, or cannot be, standardized. Among them are the process of combining various intensity channels, the process of combining analog and photon-counting channels, and the method with which to correct or remove the influence of aerosol and clouds. In particular, the method of combining various intensity channels to form a single profile depends strongly on the experimental configuration (i.e., how many channels are available, what are their wavelengths, and what are their intensities). In the next section, it will be shown that such experimental aspects actually can explain a large fraction of the differences observed between the various lidar measurements and their uncertainty during the SCOOP campaign. 

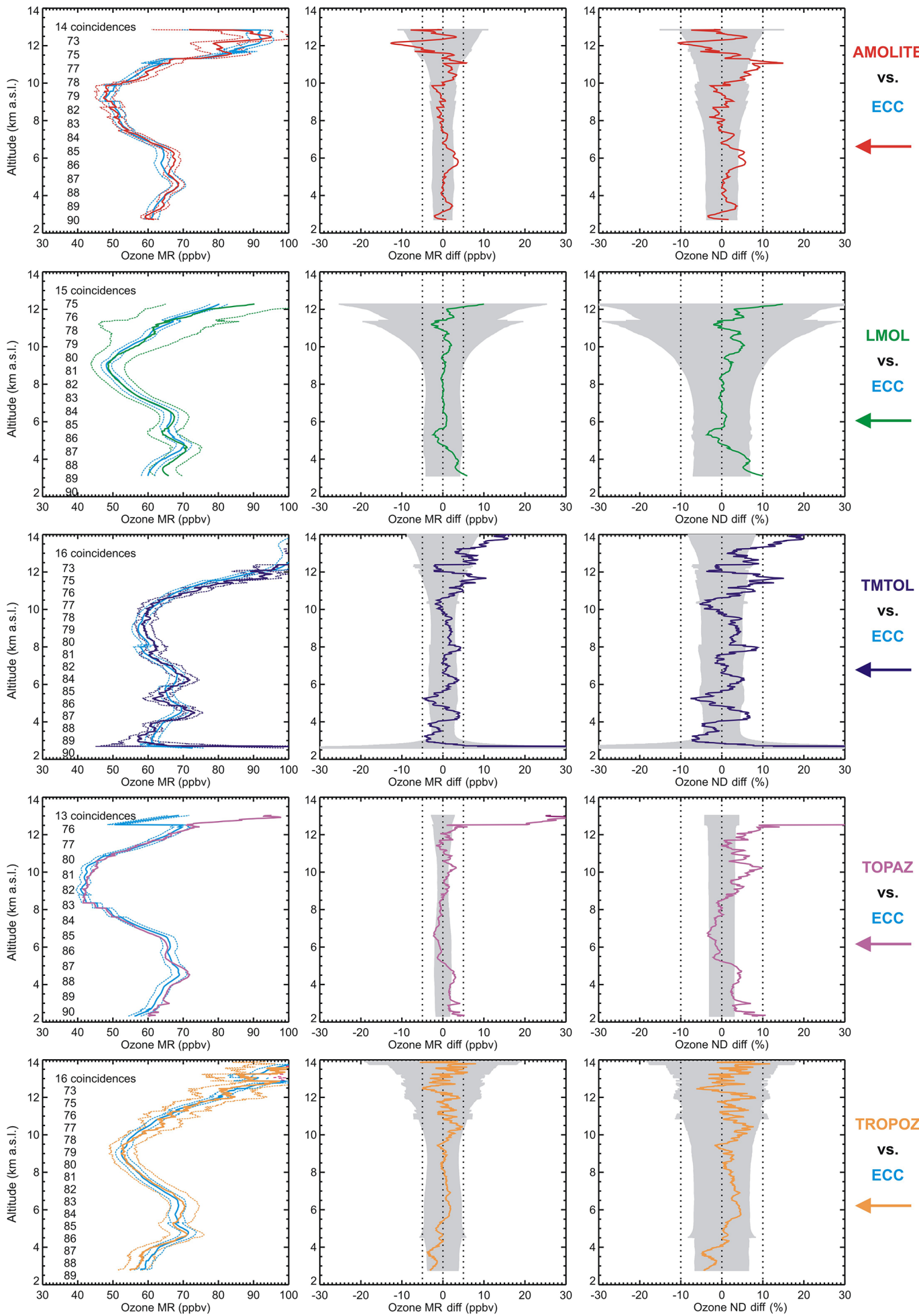

Figure 9. One-on-one ozone profile intercomparison between ECC ozonesonde (cyan curves) and lidar (from top to bottom: AMOLITE in red, LMOL in green, TMTOL in blue, TOPAZ in purple, and TROPOZ in yellow). In the left panels, the thin dotted lines represent the ozone profiles \pm uncertainty. Each coincidence is identified by the ozonesonde launch number. The middle and right panels show the differences between lidar and ozonesonde in ppbv and percent, respectively (ozonesonde is the reference). The grey-shaded areas denote the combined total uncertainty. 

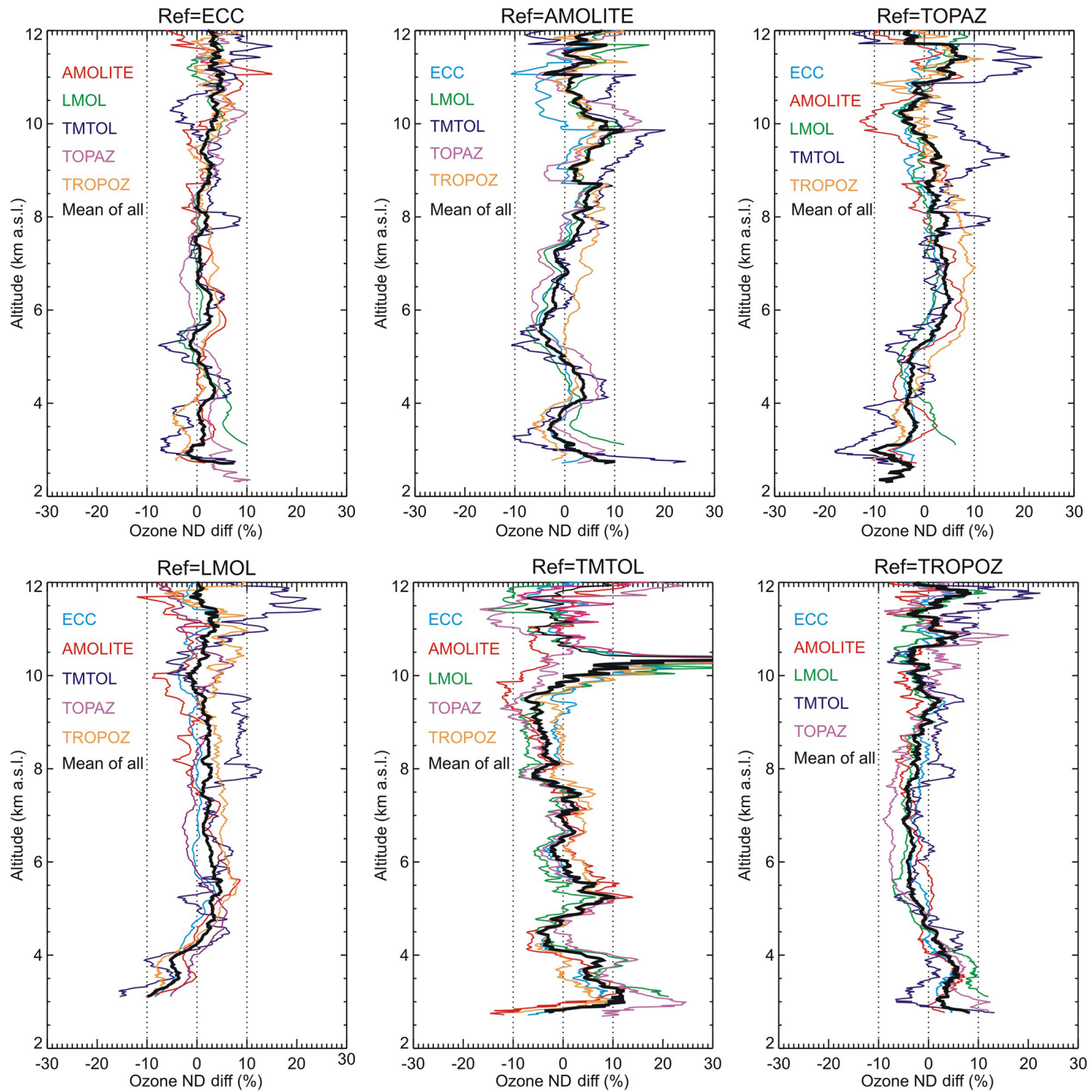

Figure 10. Mean ozone difference (\%) between one instrument (referenced on top of each panel) and all the others, computed using all available one-on-one instrument coincidences. Colored curves: one-on-one differences. Black thick curves: mean of all colored curves.

\section{SCOOP Level 2 data comparisons}

\subsection{One-on-one comparisons}

One-on-one instrument intercomparison profiles are given in Fig. 9 for all five lidar instruments with respect to the ozonesondes. The left panels show the mean ozone profiles computed using all available one-on-one coincidences between ozonesonde (cyan curves) and lidar (from top to bottom: AMOLITE in red, LMOL in green, TMTOL in blue, TOPAZ in purple, and TROPOZ in yellow). For each instrument, the thin dotted lines denote the ozone profiles $\pm 1 \sigma$ uncertainty. The middle and right panels show the ozone differences between lidar and ozonesonde in parts per billion by volume (ppbv) and in percent (\%), respectively, with the ozonesonde being the reference. The grey-shaded areas denote the combined total uncertainty (quadratic sum of each instrument's total uncertainty). No uncertainty estimate was given by the NOAA TOPAZ lidar group. The fourth row of Fig. 9 therefore includes the ozonesonde uncertainty only, which explains a smaller shaded area than for the other rows. In view of the reported uncertainty estimates, no outstanding bias can be detected for any of the instruments compared here. The main result is a consistent agreement between sonde and lidar within the combined reported uncertainties, i.e., within $3-5$ ppbv or $5 \%-8 \%$.

In order to identify possible biases owing to individual instruments, each lidar instrument was compared against all the others. The results are shown in Fig. 10. Each panel corresponds to a particular instrument, referenced at the top of each panel. The colored curves represent the mean ozone differences (in percent) between the reference instrument and another instrument, computed using all available one-on-one coincidences for this particular pair of instruments. In each 

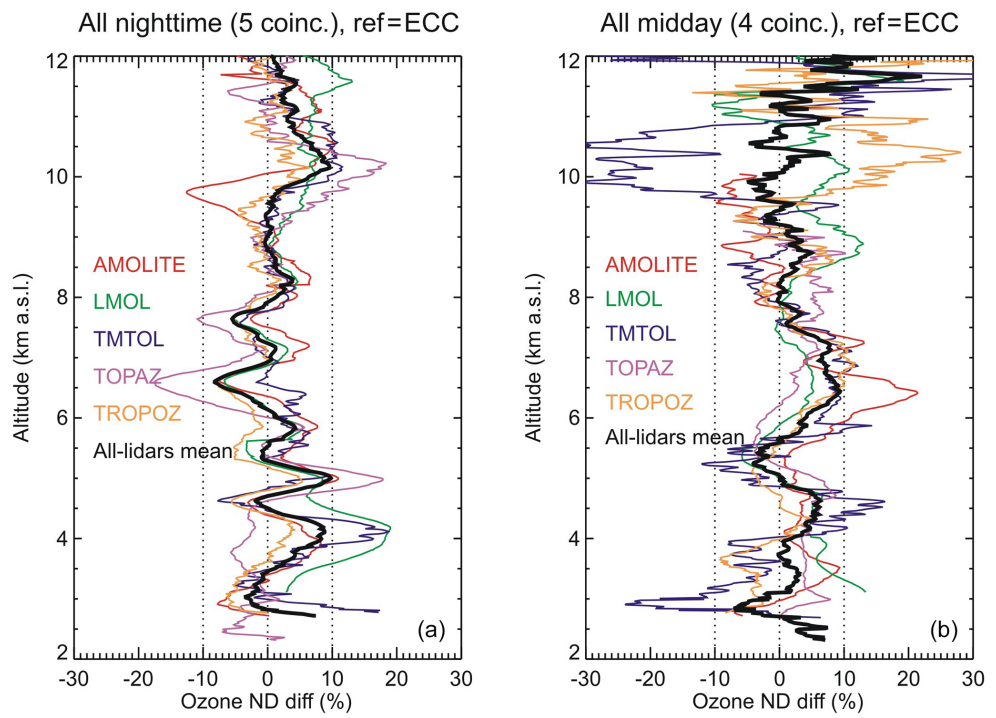

Figure 11. Same as Fig. 10 (top-left panel) but considering only nighttime measurements (a) and midday measurements (b).

panel, the thick black curve represents the mean of all colored curves. For a particular reference instrument, if the black curve displays outstanding features similar in shape and magnitude to features displayed by several colored curves, then it is likely that these features are due to the reference instrument. For example, the positive difference of $10 \%-15 \%$ and $8 \%-9 \%$ observed at around 10.5 and $5 \mathrm{~km}$ altitude, respectively, in the TMTOL panel (bottom row, middle panel) points to a likely positive bias owing to TMTOL. Several other small biases can likewise be identified, most noticeably $\mathrm{a}-8 \%$ bias below $4 \mathrm{~km}$ for LMOL and TOPAZ, a $+5 \%$ bias below $4 \mathrm{~km}$ for TROPOZ, a $+10 \%$ bias at around $3 \mathrm{~km}$ for TMTOL, and a reversed "S" shape from $-5 \%$ at $5.5 \mathrm{~km}$ to $+8 \%$ below $3 \mathrm{~km}$ for AMOLITE. The magnitude of these differences remains mostly within the reported uncertainties, and the largest differences occur in regions known to be borderline in terms of validity of the lidar measurements (e.g., the profiles' lower boundary). Interestingly, the ECC ozonesonde panel (top left) exhibits the least (if any) significant feature, which seems to indicate that no bias arises from the sonde measurements, making the ozonesonde a suitable reference transfer for the SCOOP campaign. Noticeably, the number of coincidences used to compute the means for a particular pair of instruments varies with altitude (not shown). This number maximizes in the $3-10 \mathrm{~km}$ altitude range (typically 13-16 coincidences) but quickly drops above $10 \mathrm{~km}$ and below $3 \mathrm{~km}$, which contributes to increasing the apparent magnitude of the differences in these regions. The potential loss of co-location in the upper troposphere between the drifting ozonesondes and the fixed lidars might also contribute to the slightly larger differences observed between sonde and lidar above $10 \mathrm{~km}$. Nevertheless, it is interesting to note that all five lidars exhibit a positive bias of about $5 \%$ at $11 \mathrm{~km}$ with respect to ozonesondes, which points either to a negative ozonesonde measurement bias or to a co-location error between the sondes and the lidars.

Finally, the good performance of the tunable laser instruments (LMOL and TOPAZ) with respect to the other lidar instruments is noteworthy. However, it is not clear what actually balances the lower power of the tunable lasers. Likely candidates are the overall transmission of the receivers (including optical and electronic/quantum efficiencies), the choice of the spectral filters, a higher laser repetition rate, and possibly the shorter wavelengths used, although for the latter a quick calculation of ozone absorption and atmospheric extinction differentials yields little difference with the YAG-based systems.

Figure 11 is similar to the top-left panel of Fig. 10 $(\mathrm{ref}=\mathrm{ECC})$, but with the coincidences split by local time. The left panel shows the mean ozone difference between sonde and lidar computed for all five early nighttime launches, and the right panel shows these differences for all four launches performed during midday (typically 11:00 to 14:00 LT). Not surprisingly, the differences exhibit more noise due to the reduced number of coincidences (e.g., AMOLITE at $6.5 \mathrm{~km}$ ), as well as more noise at the top of the daytime profiles (lower signal-to-noise ratio due to daylight). Note again the noisy profile for TMTOL below $6 \mathrm{~km}$, especially during daytime, as the instrument suffered from a reduced signal-to-noise ratio in 2016 (see earlier discussion).

However, no major mean bias stands out for either plot, showing that both daytime and nighttime profiles remain within the $7 \%-8 \%$ total combined uncertainty shown in the earlier figures. 

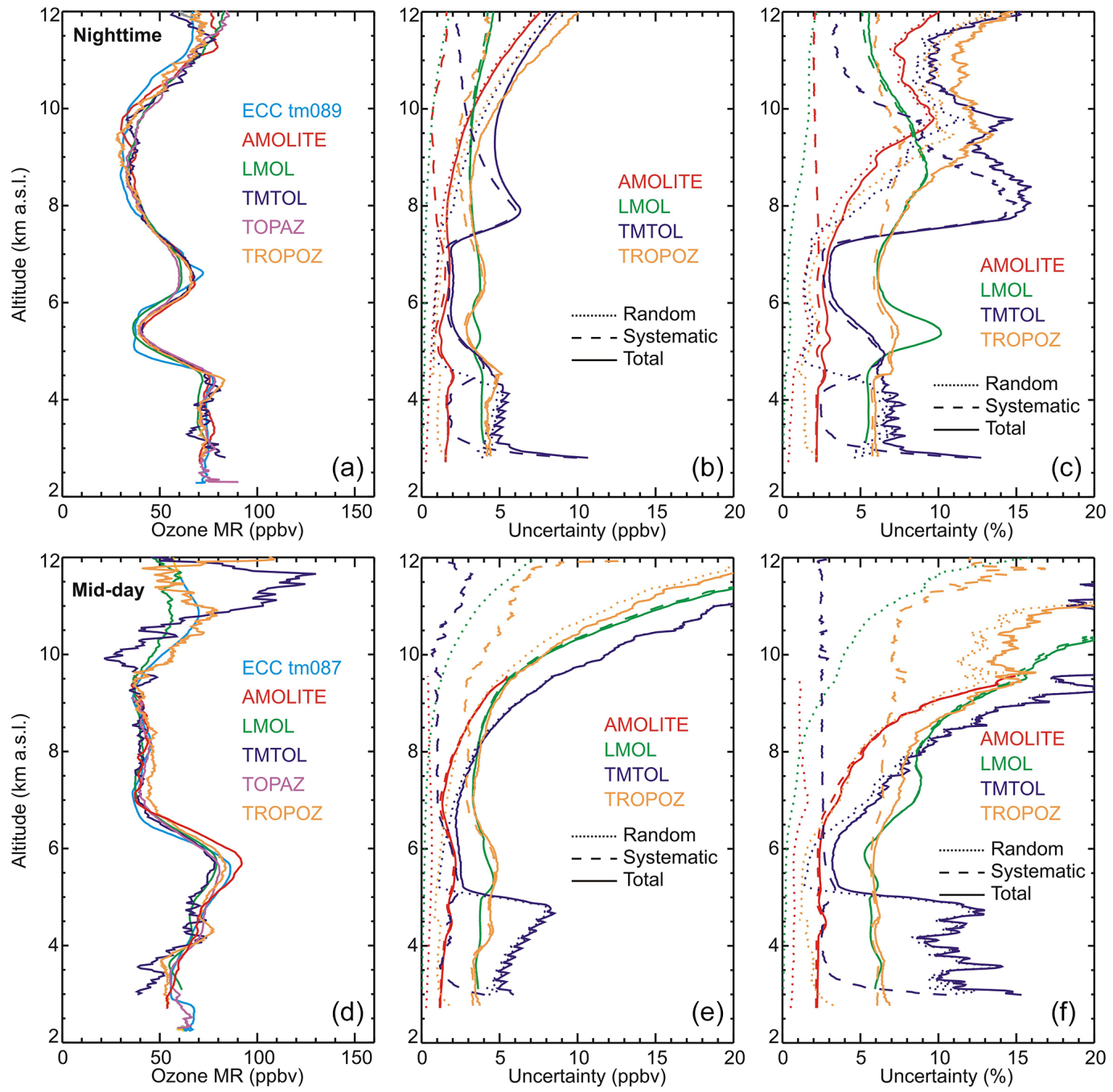

Figure 12. (a, d) Two selected 30 min ozone profiles measured simultaneously by all five lidars in dark conditions (a, b, c) and in the brightest possible daytime conditions (d, e, f). (b, e) Ozone uncertainty (in ppbv) associated with the profiles shown in (a, d). (c, f) Same as middle panels but expressed in percent. For the uncertainty plots, dotted curves denote the random component, dash curves denote the systematic component, and solid curves denote the total uncertainty.

\subsection{Uncertainties}

The presence of five TOLNet lidars operating in identical conditions, and using common data processing options, allowed for an objective assessment of their performance as a function of altitude range and time of the day, as well as an objective comparison of their reported uncertainties.

Figure 12 shows two selected 30 min ozone profiles (left panels) measured simultaneously by all five lidars in dark conditions (top) and in the brightest possible conditions (bottom), as well as their corresponding reported uncertainty expressed in parts per billion (middle panels) and percent (right panels). In the middle and right panels, the dotted curves denote the random component, the dash curves denote the systematic component, and the solid curves denote the total uncertainty (computed as the quadratic sum of random and systematic components). The dotted curves in Fig. 12 therefore correspond to the black/grey curves shown in Fig. 8, and the dash curves in Fig. 12 represent the quadratic sum of all the systematic components displayed in Fig. 8. Showing the ozone profiles (left panels) allows distinguishing between uncertainty changes associated with ozone changes and uncertainty changes inherent to the measurement technique itself (i.e., independent of the ozone content at a precise time and location). For example, the localized uncertainty peak for TMTOL at $5.5 \mathrm{~km}$ altitude (top-right panel, green curve) is essentially due to the dip in ozone mixing ratio (top-left panel) rather than a change in the uncertainty (top-middle panel, green curve, shows a nearly constant absolute systematic uncertainty). 
SCOOP-campaign-mean lidar-sonde ozone differences (reference $=$ ECC)
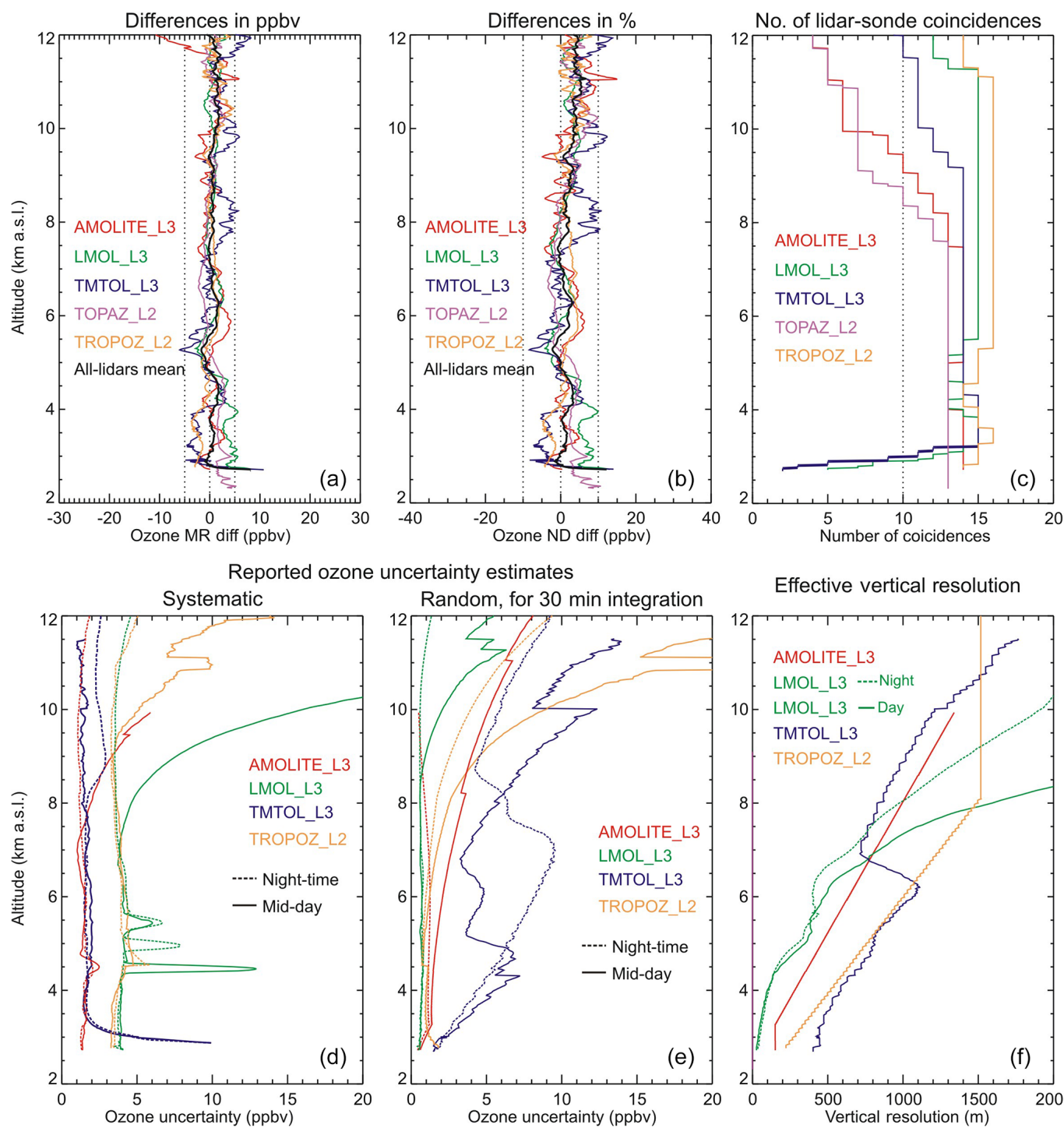

Effective vertical resolution

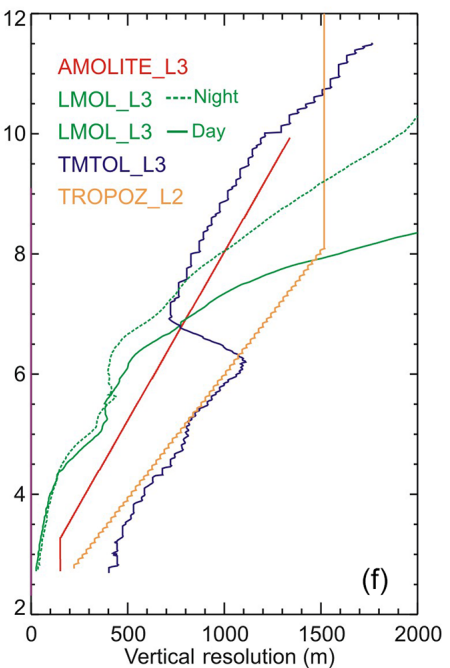

Figure 13. (a, b, c) Mean ozone differences (in ppbv) between the SCOOP Level 3 lidar data (or Level 2 if Level 3 is not available) and ozonesonde, computed using all available one-on-one coincidences during SCOOP. (b) Same as (a) but with ozone differences in percent. (c) Number of coincidences used to compute the mean differences. (d) Mean of reported systematic uncertainties. Solid curves are during brightest daytime conditions; dash curves are for nighttime conditions. (e) Same as (d) but for random uncertainties for 30 min data acquisition. (f) Reported effective vertical resolution.

The most striking feature in Fig. 12 is the difference in magnitude and shape between the uncertainty estimates computed for the various lidars. At nighttime (top row), a similar dependence on altitude holds for most lidars, specifically, a nearly constant total uncertainty of $1-4 \mathrm{ppbv}(2 \%-6 \%)$ from the lowest data point up to about $9 \mathrm{~km}$ and then an increase to about $5-10 \mathrm{ppbv}(10 \%-15 \%)$ at $12 \mathrm{~km}$. The exception is TMTOL, with a total uncertainty of 5 ppbv (7\%) below $5 \mathrm{~km}$, followed by a decrease to $2 \mathrm{ppbv}(3 \%)$ near $6-7 \mathrm{~km}$, a wide peak at $6 \mathrm{ppbv}(15 \%)$ near $8 \mathrm{~km}$, and finally a decrease to 4 ppbv $(8 \%)$ at $11 \mathrm{~km}$, before increasing again like the other lidars. This difference between TMTOL and the other lidars can be explained by the use of three intensity ranges of very different characteristics: below $5 \mathrm{~km}$, the TMTOL low-intensity channels were unusually weak during SCOOP and therefore yielded higher random uncertainty. The peak at $8 \mathrm{~km}$ comes from using a pair of very high intensity channels, therefore leading to a higher estimate of saturation correction uncertainty (blue dash curve). The estimation of this uncertainty component depends on the photon counter's dead time (provided by the manufacturer) and on the trueness of the 


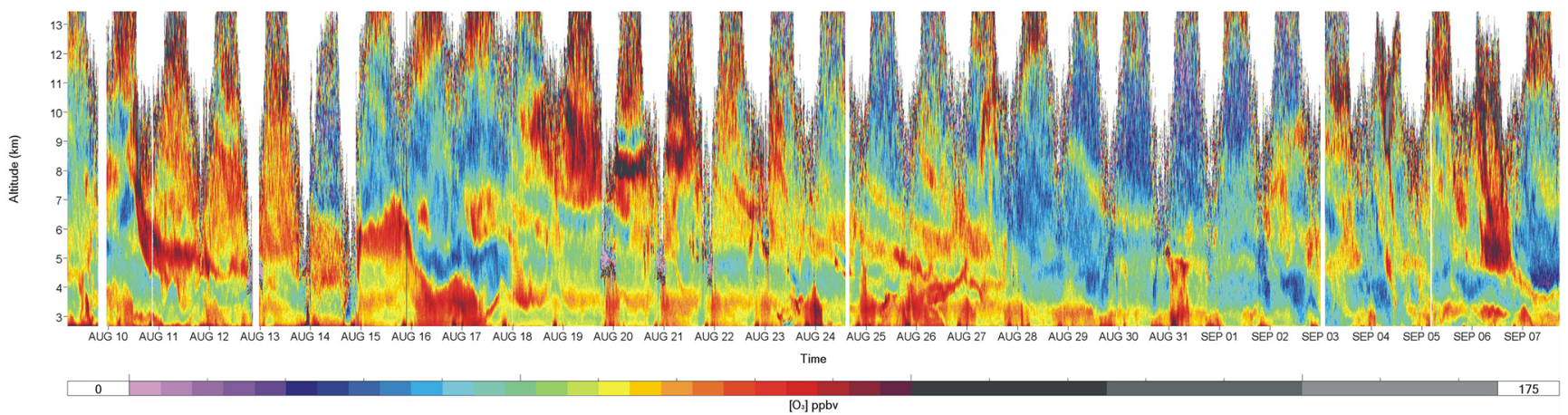

Figure 14. 31-day ozone time-altitude cross section obtained at TMF by the AMOLITE lidar during - and immediately after - the SCOOP campaign.

correction equation. It is often overestimated for the sake of choosing a conservative side.

This high-intensity pair is used for the purpose of extending the ozone profile well beyond the tropopause (typically $25 \mathrm{~km}$ ) as part of the TMTOL's mandate to produce lower stratospheric ozone profiles for NDACC. On the night of 16 August (UT), as well as several other SCOOP nights, TMTOL encountered alignment and low signal-to-noise ratio issues on the low-intensity channels, which forced the transition from low-intensity to high-intensity channels at an unusually low altitude (i.e., 7-8 km instead of the usual 12$14 \mathrm{~km}$ used routinely between 1999 and 2015). This uncertainty peak of $15 \%$ at $8 \mathrm{~km}$ is therefore not representative of TMTOL in normal conditions. Indeed, a few months after the SCOOP campaign, several aging optics in the TMTOL transmitter and receiver were replaced, and the signal-to-noise ratio was significantly improved.

The random uncertainty in the $3-12 \mathrm{~km}$ altitude range has since remained within the $7 \%-8 \%$ range when using an effective vertical resolution and integration times similar to those of the present SCOOP Level 2 data. Finally, a brief, but sharp, increase of uncertainty is also observed for LMOL at 5-6 km (green curve), and to a lesser extent for TROPOZ at $4.5 \mathrm{~km}$ (pink curve). For TROPOZ, the increase is once again explained by the transition between the low-intensity range (analog channels) and the high-intensity range (photon-counting channels), while for LMOL it is mainly due to the ozone sudden decrease at $5.5 \mathrm{~km}$ (as discussed earlier).

In the bright conditions of midday (Fig. 12, bottom row), the altitude dependence of uncertainty is similar for all lidars, once again with the exception of TMTOL. Not surprisingly, uncertainty increases quickly for all lidars from the $1-4 \mathrm{ppbv}(2 \%-6 \%)$ values already noted at nighttime to $10 \mathrm{ppbv}(15 \%)$ at around $9-10 \mathrm{~km}$ altitude and $>25 \mathrm{ppbv}$ (>30\%) at $12 \mathrm{~km}$. The random component dominates, logically explained by high background noise associated with bright daylight. Once again, TMTOL stands out with a higher random uncertainty than the other lidars below $5 \mathrm{~km}(5-$
8 ppbv, $10 \%-12 \%$ ), again associated with the low signal-tonoise ratio of the low-intensity channels during SCOOP.

\section{SCOOP Level 3 data and final validation outcome}

The blind phase of the TOLNet lidar validation efforts during the SCOOP campaign, together with a thorough TOLNet data processing algorithm validation exercise, represented key steps of the TOLNet lidar quality assessment and quality control (QA/QC) process. For the AMOLITE, LMOL, and TMTOL lidars, these measurement and retrieval validation efforts led to the production of optimized ozone profiles, referred to as "SCOOP Level 3" data. With this data version, the ozone profiles' effective vertical resolution scheme is optimized and depends on the lidar considered (yet using the same NDACC-standardized definition). For the TOPAZ and TROPOZ lidars, the in-house algorithm had been validated prior to SCOOP, and the vertical resolution scheme used for the SCOOP Level 2 data was suitable enough to be kept as is. Therefore no data version change from Level 2 to Level 3 was therefore necessary.

Figure 13, top row, shows the mean differences (left panel: in ppbv; middle panel: in percent) between the SCOOP Level 3 ozone lidar profiles and the ozonesonde profiles for all available one-on-one lidar-sonde coincidences (Level 2 data are shown for TROPOZ and TOPAZ). The right panel shows the number of coincidence pairs used for each instrument as a function of altitude. The lidar-ozonesonde differences remain within $\pm 5 \mathrm{ppbv}(8 \%-10 \%)$, but this is now taking into account an additional smoothing error (the AMOLITE, LMOL, and TMTOL effective vertical resolutions are no longer matching). Just like in Figs. 10 and 11, the thick black curve represents the mean of all the colored lines present on the same plot. Taken as a whole, the TOLNet lidars show excellent agreement with the ECC ozonesondes, with an overall mean bias of $0.7 \mathrm{ppbv}$, or $1.7 \%$, for the altitude range 3 $10 \mathrm{~km}$, and with a root-mean-square deviation of $1.6 \mathrm{ppbv}$, or 
$2.4 \%$, although Table 5 shows sometimes larger bias or root mean square (rms) for a single system.

The bottom row of Fig. 13 shows the mean of systematic (left panel) and random (middle panel) uncertainties associated with the coincidence pairs used to plot the ozone differences showed in the top row, as well as the reported effective vertical resolution (right panel). Table 5 summarizes the bias, precision, and accuracy estimates of all the instruments, taken either separately or as a whole. The six panels of Fig. 13 altogether conclude the SCOOP validation efforts and summarize well the overall quality of the five TOLNet lidars that participated in the campaign. They provide, together with Table 5 and Fig. 10 (top-left panel), an excellent QA/QC review for the AMOLITE, LMOL, TMTOL, TOPAZ, and TROPOZ lidar data, which can be used as a reference in future process studies and satellite validation efforts using these data.

\section{Summary}

Despite stringent air quality regulations put in place decades ago in many countries around the world, free-tropospheric ozone increase has continued to increase in certain regions, including the western United States. This increase contributed to the decision to expand tropospheric ozone observation capabilities in North America through the establishment of the TOLNet lidar network. In August 2016, five of the six TOLNet lidars (namely, AMOLITE, LMOL, TMTOL, TOPAZ, and TROPOZ) participated in the SCOOP intercomparison and validation campaign at the JPL Table Mountain Facility in California. After significant efforts validating the TOLNet data processing algorithms, the SCOOP campaign provided an unprecedented opportunity to validate the simultaneous measurements of five co-located tropospheric ozone lidars.

Approximately $400 \mathrm{~h}$ of lidar measurements were made, and 17 ozonesondes were launched over the 1-week-long campaign, allowing for a thorough validation of the lidars. Over the range of 3-10 km a.s.l., the mean difference between lidar and ozonesonde was found to be $0.7 \mathrm{ppbv}$ $(1.7 \%)$, with rms deviation of $1.6 \mathrm{ppbv}$, or $2.4 \%$, which is well within the combined reported uncertainties of lidar and sonde (Table 5). When compared to previous intercomparison campaigns, these estimates are fully consistent with the $1.2 \%-4 \%$ differences found by Wang et al. (2017) and 2\% lidar-sonde differences found by Papayannis et al. (2005), and they are smaller than the 10\%-20\% estimates reported in Kuang et al. (2011). The rare and minor differences identified here were typically associated with the known limitations of the lidars at the profiles boundaries, for example, errors associated with incomplete beam-telescope overlap and signal saturation at the bottom of the profiles (below $3-4 \mathrm{~km}$ a.s.1.), and random noise at the top of the profiles (above $10 \mathrm{~km}$ a.s.l.). Geophysical variability, and the fact that the ozonesonde is no longer co-located with the lidars higher up, is also believed to contribute to some of the differences observed in the upper troposphere. Together with the measurements, many aspects of the data processing algorithms such as ozone absorption cross sections, the definition of effective vertical resolution, and the uncertainty budget - were standardized and validated. This thorough validation of both the measurements and retrievals gives high confidence in the quality and reliability of the TOLNet ozone lidar profiles.

\section{Conclusion and perspectives}

After several years of instrumental development and optimization, the SCOOP campaign represents a turning point in the lifecycle of TOLNet. Upon their deployment in Southern California in August 2016, the participating TOLNet lidars had reached a mature stage of technical development. The 1week-long SCOOP campaign represented the most comprehensive and rigorous TOLNet ozone lidar intercomparison yet. In particular, its focus on algorithm testing and homogenization ensures that TOLNet ozone lidar network data will be of the highest quality for years to come. The results of this campaign demonstrate the excellent accuracy of the tropospheric ozone lidar technique, which is expected to be used more intensively in the decades to come for high-verticalresolution profiling of tropospheric ozone. In this respect, TOLNet has the potential to become the first continentalscale high-quality ozone lidar network that could be operated over an extended period of time.

As part of its technical expertise development, TOLNet is now striving to provide more automated, autonomous field measurements. Figure 14 shows a 31-day ozone timealtitude cross section obtained at TMF by the AMOLITE lidar during, and immediately after the SCOOP campaign. It illustrates nicely the full capability of an autonomous and automated tropospheric ozone lidar. Today, several other TOLNet lidars (e.g., TMTOL) are testing/implementing this new mode of operation. As technology improves and becomes more reliable and affordable, it is expected that most TOLNet instruments will converge towards autonomous operations. This mode of operation opens the door to advanced process studies (e.g., extended ozone diurnal variability studies) and will likely lead to the production of extensive groundbased reference datasets for process studies, as well as model and satellite validation. One example is the validation of the TROPOMI instrument on board the European satellite Sentinel 5P. For a given location, this instrument measures ozone at the same local time (13:00 LT) every day. In 2017, the TMTOL lidar was upgraded to operate autonomously, upon demand. It was programmed to run automatically for $1 \mathrm{~h}$ every day at approximately 13:00 LT, and it has since acquired more than 150 correlative profiles for the validation of TROPOMI. Another application is the validation of the future NASA instrument TEMPO to be launched to a geo- 
Table 5. Summary of mean biases found during SCOOP between a single instrument and all the other ones, and summary of key statistics characterizing the lidar instruments' capability.

\begin{tabular}{|c|c|c|c|c|c|c|}
\hline $\begin{array}{l}\text { All altitudes: a.s.l. } \\
\text { Ground is at } 2.3 \mathrm{~km}\end{array}$ & $\begin{array}{l}\text { All lidars } \\
\text { w.r.t. ECC }\end{array}$ & $\begin{array}{l}\text { AMOLITE } \\
\text { w.r.t. all others }\end{array}$ & $\begin{array}{l}\text { LMOL } \\
\text { w.r.t. all others }\end{array}$ & $\begin{array}{l}\text { TMTOL } \\
\text { w.r.t. all others }\end{array}$ & $\begin{array}{l}\text { TOPAZ } \\
\text { w.r.t. all others }\end{array}$ & $\begin{array}{l}\text { TROPOZ } \\
\text { w.r.t. all others }\end{array}$ \\
\hline Mean bias 6 & $1.7 \%$ & $1.9 \%$ & $1.5 \%$ & $-1.2 \%$ & $1.3 \%$ & $-1.6 \%$ \\
\hline $3-10 \mathrm{~km}$ & $0.7 \mathrm{ppbv}$ & $0.2 \mathrm{ppbv}$ & $0.3 \mathrm{ppbv}$ & $-0.1 \mathrm{ppbv}$ & $0.5 \mathrm{ppbv}$ & $-0.4 \mathrm{ppbv}$ \\
\hline $\mathrm{rms}^{6}$ & $2.4 \%$ & $4.4 \%$ & $3.1 \%$ & $5.1 \%$ & $3.1 \%$ & $3.5 \%$ \\
\hline $3-10 \mathrm{~km}$ & $1.6 \mathrm{ppbv}$ & $2.2 \mathrm{ppbv}$ & $1.6 \mathrm{ppbv}$ & $3.4 \mathrm{ppbv}$ & $1.8 \mathrm{ppbv}$ & $1.9 \mathrm{ppbv}$ \\
\hline $\begin{array}{l}\text { Effect. vert. resol. } \\
3-5 \mathrm{~km}\end{array}$ & I & $300 \mathrm{~m}$ & $150 \mathrm{~m}$ & $600 \mathrm{~m}^{2}$ & $500 \mathrm{~m}^{1}$ & $500 \mathrm{~m}^{1}$ \\
\hline $\begin{array}{l}\text { Precision }(30 \mathrm{~min}) \\
3-5 \mathrm{~km}\end{array}$ & I & $1.5 \mathrm{ppbv}$ & $1 \mathrm{ppbv}$ & $5 \mathrm{ppbv}^{2}$ & $\begin{array}{l}\text { Not } \\
\text { available }\end{array}$ & $1.5 \mathrm{ppbv}$ \\
\hline $\begin{array}{l}\text { Effect. vert. resol. } \\
5-8 \mathrm{~km}\end{array}$ & I & $700 \mathrm{~m}$ & $600 \mathrm{~m}$ & $900 \mathrm{~m}^{2}$ & $1000 \mathrm{~m}^{1}$ & $1000 \mathrm{~m}^{1}$ \\
\hline $\begin{array}{l}\text { Precison }(30 \mathrm{~min}) \\
5-8 \mathrm{~km}\end{array}$ & I & $\begin{array}{l}\text { Night: } \\
2.5 \mathrm{ppbv} \\
\text { Day: } 1.5 \mathrm{ppbv}\end{array}$ & $1 \mathrm{ppbv}$ & $\begin{array}{l}\text { Night: } 9 \text { ppbv }^{2} \\
\text { Day: } 4 \text { ppbv }^{3}\end{array}$ & $\begin{array}{l}\text { Not } \\
\text { available }\end{array}$ & $1.5 \mathrm{ppbv}$ \\
\hline $\begin{array}{l}\text { Effect. vert. resol. } \\
8-11 \mathrm{~km}\end{array}$ & I & $1400 \mathrm{~m}$ & $2000 \mathrm{~m}$ & $1000 \mathrm{~m}^{3}$ & $1500 \mathrm{~m}^{1}$ & $1500 \mathrm{~m}^{1}$ \\
\hline $\begin{array}{l}\text { Precision (30 min) } \\
8-11 \mathrm{~km}\end{array}$ & I & $\begin{array}{l}\text { Night: } 5 \text { ppbv } \\
\text { Day: } 1.5 \mathrm{ppbv}\end{array}$ & $\begin{array}{l}\text { Night: } 1 \text { ppbv } \\
\text { Day: } 2 \text { ppbv }\end{array}$ & $\begin{array}{l}\text { Night: } 5 \mathrm{ppbv}^{3} \\
\text { Day: } 9 \mathrm{ppbv}^{3}\end{array}$ & $\begin{array}{l}\text { Not } \\
\text { available }\end{array}$ & $\begin{array}{l}\text { Night: } 3 \text { ppbv } \\
\text { Day: } 7 \text { ppbv }\end{array}$ \\
\hline $\begin{array}{l}\text { Systematic uncert. } \\
3-8 \mathrm{~km}\end{array}$ & I & $2 \mathrm{ppbv}$ & $4 \mathrm{ppbv}$ & $2 \mathrm{ppbv}$ & $\begin{array}{l}\text { Not } \\
\text { available }\end{array}$ & $4 \mathrm{ppbv}$ \\
\hline $\begin{array}{l}\text { Systematic uncert. } \\
8-11 \mathrm{~km}\end{array}$ & I & $\begin{array}{l}\text { Night: } 2 \text { ppbv } \\
\text { Day: } 4 \text { ppbv } 5\end{array}$ & $\begin{array}{l}\text { Night: } 4 \text { ppbv } \\
\text { Day: } 10 \mathrm{ppbv}^{5}\end{array}$ & $\begin{array}{l}\text { Night: } 3 \text { ppbv }^{4} \\
\text { Day: } 2 \text { ppbv }\end{array}$ & $\begin{array}{l}\text { Not } \\
\text { available }\end{array}$ & $\begin{array}{l}\text { Night: } 4 \text { ppbv } \\
\text { Day: } 5 \text { ppbv } 5\end{array}$ \\
\hline
\end{tabular}

stationary orbit in 2020/2021. For a given location in North America, this instrument will measure tropospheric ozone during daytime at $1 \mathrm{~h}$ intervals with high horizontal resolution. The TMTOL lidar, and likely several other TOLNet lidars, will be programmed to measure for a few minutes every $1 \mathrm{~h}$ during daytime, 7 days a week, which will provide a maximum number of correlative measurements with TEMPO yet minimize instrumental wear-out.

In addition to automated measurements, TOLNet is working towards extending the lidars' measurement range downward to about $100 \mathrm{~m}$ above ground. The TOPAZ system can already measure ozone at even lower range $(25 \mathrm{~m}$ above ground) thanks to their scanning transmitter mirror, and assuming homogeneous ozone field in the vicinity of the instrument deployment site. Other TOLNet groups (e.g., TMTOL, LMOL) just started to provide valid measurements down to $100 \mathrm{~m}$ above ground (Chouza et al., 2018; Farris et al., 2018). Finally, additional coordinated efforts within TOLNet are planned to provide improved ozone retrievals including an aerosol correction. Several groups (e.g., TOPAZ) have previ- ously implemented an optional correction, and future efforts within TOLNet will concentrate on the possible homogenization of such a correction across the network.

Code availability. Questions pertaining to the methods and approaches used to perform the comparison and validation results presented here should be directed to the first author at thierry.leblanc@jpl.nasa.gov.

Data availability. All ozonesonde and ozone lidar profiles shown here, and obtained during SCOOP, are publicly available at the TOLNet website https://www-air.larc.nasa.gov/missions/TOLNet, or can be obtained by submitting a request to the participating lidar instrument PIs (authors of this paper).

Competing interests. The authors declare that they have no conflict of interest. 
Acknowledgements. The work described here was in part carried out at the Jet Propulsion Laboratory, California Institute of Technology, under agreements with the National Aeronautics and Space Administration. The Tropospheric Ozone Lidar Network and the SCOOP campaign acknowledge funding from the Tropospheric Chemistry Program of the NASA Earth Science and Division. The NOAA/ESRL lidar operations were also supported by the NOAA Climate Program Office, Atmospheric Chemistry, Carbon Cycle, and Climate (AC4) Program. The views, opinions, and findings contained in this report are those of the author(s) and should not be construed as an official National Oceanic and Atmospheric Administration or U.S. Government position, policy, or decision. AMOLITE's participation was supported by the Environment and Climate Change Canada's Climate Change and Air Quality Program (CCAP) and the Joint Oil Sands Monitoring program (JOSM).

Edited by: Ulla Wandinger

Reviewed by: two anonymous referees

\section{References}

Alvarez, R. J., Senff, C. J., Langford, A. O., Weickmann, A. M., Law, D. C., Machol, J. L., Merritt, D. A., Marchbanks, R. D., Sandberg, S. P., Brewer, W. A., Hardesty, R. M., and Banta, R. M.: Development and Application of a Compact, Tunable, Solid-State Airborne Ozone Lidar System for Boundary Layer Profiling, J. Atmos. Ocean Tech., 28, 1258-1272, https://doi.org/10.1175/jtech-d-10-05044.1, 2011.

Browell, E. V., Ismail, S., and Shipley, S. T.: Ultraviolet DIAL measurements of $\mathrm{O}_{3}$ profiles in regions of spatially inhomogeneous aerosols, Appl. Opt., 24, 2827-2836, https://doi.org/10.1364/ao.24.002827, 1985.

Cooper, O. R., Gao, R. S., Tarasick, D., Leblanc, T., and Sweeney, C.: Long-term ozone trends at rural ozone monitoring sites across the United States, 1990-2010, J. Geophys. Res., 117, D22307, https://doi.org/10.1029/2012jd018261, 2012.

Daumont, D., Brion, J., Charbonnier, J., and Malicet, J.: Ozone UV Spectroscopy I: Absorption Cross-Sections at Room Temperature, J. Atmos Chem., 15, 145-155, https://doi.org/10.1007/bf00053756, 1992.

De Mazière, M., Thompson, A. M., Kurylo, M. J., Wild, J. D., Bernhard, G., Blumenstock, T., Braathen, G. O., Hannigan, J. W., Lambert, J.-C., Leblanc, T., McGee, T. J., Nedoluha, G., Petropavlovskikh, I., Seckmeyer, G., Simon, P. C., Steinbrecht, W., and Strahan, S. E.: The Network for the Detection of Atmospheric Composition Change (NDACC): history, status and perspectives, Atmos. Chem. Phys., 18, 4935-4964, https://doi.org/10.5194/acp-18-4935-2018, 2018.

De Young, R., Carrion, W., Ganoe, R., Pliutau, D., Gronoff, G., Berkoff, T., and Kuang, S.: Langley mobile ozone lidar: ozone and aerosol atmospheric profiling for air quality research, Appl. Opt., 56, 721-730, https://doi.org/10.1364/ao.56.000721, 2017.

Farris, B. M., Gronoff, G. P., Carrion, W., Knepp, T., Pippin, M., and Berkoff, T. A.: Demonstration of an off-axis parabolic receiver for near-range retrieval of lidar ozone profiles, Atmos. Meas. Tech. Discuss., https://doi.org/10.5194/amt-2018-178, in review, 2018.
Gaudel, A., Cooper, O. R., Ancellet G., et al.: Tropospheric Ozone Assessment Report: Present-day distribution and trends of tropospheric ozone relevant to climate and global atmospheric chemistry model evaluation, Elem. Sci. Anth., 6, 39, 2018.

Granados-Muñoz, M. J. and Leblanc, T.: Tropospheric ozone seasonal and long-term variability as seen by lidar and surface measurements at the JPL-Table Mountain Facility, California, Atmos. Chem. Phys., 16, 9299-9319, https://doi.org/10.5194/acp16-9299-2016, 2016.

Gronoff, G., Robinson, J., Berkoff, T., Swap, R., Farris, B., Schroeder, J., Halliday, H., Knepp, T., Spinei, H., Carrion, W., Adcock, E., Johns, Z., Allen, D., and Pippin, M.: A Method for Observing Near Range Point Source Induced $\mathrm{O}_{3}$ Titration Events Using Co-located Lidar and Pandora measurements, Atmos. Environ., in review, 2018.

IPCC: Summary for Policymakers, in: Climate Change 2013: The Physical Science Basis, Contribution of Working Group I to the Fifth Assessment Report of the Intergovernmental Panel on Climate Change, edited by: Stocker, T. F., Qin, D., Plattner, G.-K., Tignor, M., Allen, S. K., Boschung, J., Nauels, A., Xia, Y., Bex, V., and Midgley, P. M., Cambridge University Press, Cambridge, UK and New York, NY, USA, 2013.

Johnson, M. S., Liu, X., Zoogman, P., Sullivan, J., Newchurch, M. J., Kuang, S., Leblanc, T., and McGee, T.: Evaluation of potential sources of a priori ozone profiles for TEMPO tropospheric ozone retrievals, Atmos. Meas. Tech., 11, 3457-3477, https://doi.org/10.5194/amt-11-3457-2018, 2018.

Kempfer, U., Carnuth, W., Lotz, R., and Trickl, T.: A wide-range ultraviolet lidar system for tropospheric ozone measurements: Development and application, Rev. Sci. Instr., 65, 3145-3164, https://doi.org/10.1063/1.1144769, 1994.

Komhyr, W. D.: Electrochemical concentration cells for gas analysis, Ann. Geophys., 25, 203-210, 1969.

Kuang, S., Newchurch, M. J., Burris, J., and Liu, X.: Ground-based lidar for atmospheric boundary layer ozone measurements, Appl. Opt., 52, 3557-3566, https://doi.org/10.1364/ao.52.003557, 2013.

Langford, A. O., Brioude, J., Cooper, O. R., Senff, C. J., Alvarez, R. J., Hardesty, R. M., Johnson, B. J., and Oltmans, S. J.: Stratospheric influence on surface ozone in the Los Angeles area during late spring and early summer of 2010, J. Geophys. Res., 117, D00V06, https://doi.org/10.1029/2011JD016766, 2012.

Langford, A. O., Senff, C. J., Alvarez Ii, R. J., Brioude, J., Cooper, O. R., Holloway, J. S., Lin, M. Y., Marchbanks, R. D., Pierce, R. B., Sandberg, S. P., Weickmann, A. M., and Williams, E. J.: An overview of the 2013 Las Vegas Ozone Study (LVOS): Impact of stratospheric intrusions and long-range transport on surface air quality, Atmos. Environ., 109, 305-322, https://doi.org/10.1016/j.atmosenv.2014.08.040, 2015.

Langford, A. O., Alvarez II, R. J., Kirgis, G., Senff, C., Caputi, J. D., Conley, S. A., Faloona, I. C., Iraci, L. T., Marrero, J. E., McNamara, M. E., Ryoo, J.-M., and Yates, E. L.: Lidar and aircraft profiling of ozone above the central 1 San Joaquin Valley during the California Baseline Ozone Transport Study (CABOTS), J. Geophys. Res., in review, 2018.

Leblanc, T., Walsh, T. D., McDermid, I. S., Toon, G. C., Blavier, J.-F., Haines, B., Read, W. G., Herman, B., Fetzer, E., Sander, S., Pongetti, T., Whiteman, D. N., McGee, T. G., Twigg, L., Sumnicht, G., Venable, D., Calhoun, M., Dirisu, A., Hurst, D., Jordan, 
A., Hall, E., Miloshevich, L., Vömel, H., Straub, C., Kampfer, N., Nedoluha, G. E., Gomez, R. M., Holub, K., Gutman, S., Braun, J., Vanhove, T., Stiller, G., and Hauchecorne, A.: Measurements of Humidity in the Atmosphere and Validation Experiments (MOHAVE)-2009: overview of campaign operations and results, Atmos. Meas. Tech., 4, 2579-2605, https://doi.org/10.5194/amt4-2579-2011, 2011.

Leblanc, T., McDermid, I. S., and Walsh, T. D.: Ground-based water vapor raman lidar measurements up to the upper troposphere and lower stratosphere for long-term monitoring, Atmos. Meas. Tech., 5, 17-36, https://doi.org/10.5194/amt-5-17-2012, 2012.

Leblanc, T., Sica R., van Gijsel, J. A. E., Godin-Beekmann, S., Haefele, A., Trickl, T., Payen, G., and Liberti, G.: Standardized definition and reporting of vertical resolution and uncertainty in the NDACC lidar ozone and temperature algorithms, ISSI Team on NDACC Lidar Algorithms Report, available at: http: //www.issibern.ch/teams/ndacc/ISSI_Team_Report.htm (last access: 7 November 2018), 2015.

Leblanc, T., Sica, R. J., van Gijsel, J. A. E., Godin-Beekmann, S., Haefele, A., Trickl, T., Payen, G., and Gabarrot, F.: Proposed standardized definitions for vertical resolution and uncertainty in the NDACC lidar ozone and temperature algorithms Part 1: Vertical resolution, Atmos. Meas. Tech., 9, 4029-4049, https://doi.org/10.5194/amt-9-4029-2016, 2016a.

Leblanc, T., Sica, R. J., van Gijsel, J. A. E., Godin-Beekmann, S., Haefele, A., Trickl, T., Payen, G., and Liberti, G.: Proposed standardized definitions for vertical resolution and uncertainty in the NDACC lidar ozone and temperature algorithms - Part 2: Ozone DIAL uncertainty budget, Atmos. Meas. Tech., 9, 4051-4078, https://doi.org/10.5194/amt-9-4051-2016, 2016b.

Malicet, J., Daumont, D., Charbonnier, J., Parisse, C., Chakir, A., and Brion, J.: Ozone uv spectroscopy 2, Absorption crosssections and temperature-dependence, J. Atmos. Chem., 21, 263-273, https://doi.org/10.1007/bf00696758, 1995

McDermid, I. S., Godin, S. M., and Walsh, T. D.: Results from the Jet-Propulsion-Laboratory stratospheric ozone lidar during STOIC 1989, J. Geophys. Res., 100, 9263-9272, https://doi.org/10.1029/94jd02148, 1995.

McDermid, I. S., Beyerle, G., Haner, D. A., and Leblanc, T.: Redesign and improved performance of the tropospheric ozone lidar at the Jet Propulsion Laboratory Table Mountain Facility, Appl. Opt., 41, 7550-7555, 2002.

Nakazato, M., Nagai, T., Sakai, T., and Hirose, Y.: Tropospheric ozone differential-absorption lidar using stimulated Raman scattering in carbon dioxide, Appl. Opt., 46, 2269-2279, https://doi.org/10.1364/ao.46.002269, 2007.

Newsom, R. K., Turner, D. D., Mielke, B., Clayton, M., Ferrare, R., and Sivaraman, C.: Simultaneous analog and photon counting detection for Raman lidar, Appl. Opt., 48, 3903-3914, 2009.

Papayannis, A., Balis, D., Zanis, P., Galani, E., Wernli, H., Zerefos, C., Stohl, A., Eckhardt, S., and Amiridis, V.: Sampling of an STT event over the Eastern Mediterranean region by lidar and electrochemical sonde, Ann. Geophys., 23, 2039-2050, https://doi.org/10.5194/angeo-23-2039-2005, 2005

Savitzky, A. and Golay, M. J. E.: Smoothing and differentiation of data by simplified least squares procedures, Anal. Chem., 36, 1627-1639, 1964.

Senff, C. J., Alvarez II, R. J., Hardesty, R. M., Banta, R. M. and Langford, A. O.: Airborne lidar measurements of ozone flux downwind of Houston and Dallas, J. Geophys. Res., 115, D20307, doi:10.1029/2009JD013689, 2010.

Smit, H. G. J., Straeter, W., Johnson, B. J., Oltmans, S. J., Davies, J., Tarasick, D. W., Hoegger, B., Stubi, R., Schmidlin, F. J., Northam, T., Thompson, A. M., Witte, J. C., Boyd, I., and Posny, F.: Assessment of the performance of ECC-ozonesondes under quasi-flight conditions in the environmental simulation chamber: Insights from the Juelich Ozone Sonde Intercomparison Experiment (JOSIE), J. Geophys. Res., 112, D19306, https://doi.org/10.1029/2006jd007308, 2007.

Strawbridge, K. B.: Developing a portable, autonomous aerosol backscatter lidar for network or remote operations, Atmos. Meas. Tech., 6, 801-816, https://doi.org/10.5194/amt-6-8012013, 2013.

Strawbridge, K. B., Travis, M. S., Firanski, B. J., Brook, J. R., Staebler, R., and Leblanc, T.: A fully autonomous ozone, aerosol and night time water vapor LIDAR: a synergistic approach to profiling the atmosphere in the Canadian oil sands region, Atmos. Meas. Tech. Discuss., https://doi.org/10.5194/amt-2018-108, in review, 2018.

Sullivan, J. T., McGee, T. J., Sumnicht, G. K., Twigg, L. W., and Hoff, R. M.: A mobile differential absorption lidar to measure sub-hourly fluctuation of tropospheric ozone profiles in the Baltimore-Washington, D.C. region, Atmos. Meas. Tech., 7, 3529-3548, https://doi.org/10.5194/amt-7-3529-2014, 2014.

Sullivan, J. T., McGee, T. J., Leblanc, T., Sumnicht, G. K., and Twigg, L. W.: Optimization of the GSFC TROPOZ DIAL retrieval using synthetic lidar returns and ozonesondes - Part 1: Algorithm validation, Atmos. Meas. Tech., 8, 4133-4143, https://doi.org/10.5194/amt-8-4133-2015, 2015.

Sullivan, J. T., McGee, T. J., Langford, A. O., Alvarez, R. J., Senff, C. J., Reddy, P. J., Thompson, A. M., Twigg, L. W., Sumnicht, G. K., Lee, P., Weinheimer, A., Knote, C., Long, R. W., and Hoff, R. M.: Quantifying the contribution of thermally driven recirculation to a high-ozone event along the Colorado Front Range using lidar, J. Geophys. Res.-Atmos., 121, 10377-10390, https://doi.org/10.1002/2016JD025229, 2016.

Vogelmann, H., Sussmann, R., Trickl, T., and Borsdorff, T.: Intercomparison of atmospheric water vapor soundings from the differential absorption lidar (DIAL) and the solar FTIR system on Mt. Zugspitze, Atmos. Meas. Tech., 4, 835-841, https://doi.org/10.5194/amt-4-835-2011, 2011.

Wang, L., Newchurch, M. J., Alvarez II, R. J., Berkoff, T. A., Brown, S. S., Carrion, W., De Young, R. J., Johnson, B. J., Ganoe, R., Gronoff, G., Kirgis, G., Kuang, S., Langford, A. O., Leblanc, T., McDuffie, E. E., McGee, T. J., Pliutau, D., Senff, C. J., Sullivan, J. T., Sumnicht, G., Twigg, L. W., and Weinheimer, A. J.: Quantifying TOLNet ozone lidar accuracy during the 2014 DISCOVER-AQ and FRAPPÉ campaigns, Atmos. Meas. Tech., 10, 3865-3876, https://doi.org/10.5194/amt10-3865-2017, 2017.

Weber, M., Gorshelev, V., and Serdyuchenko, A.: Uncertainty budgets of major ozone absorption cross sections used in UV remote sensing applications, Atmos. Meas. Tech., 9, 4459-4470, https://doi.org/10.5194/amt-9-4459-2016, 2016.

World Health Organization: Health aspects of air pollution with particulate matter, ozone and nitrogen dioxide: report on a WHO working group, 13-15 January 2003, Bonn, Germany, 2003 
World Meteorological Organization: Quality Assurance and Quality Control for Ozonesonde Measurements in GAW, October 2014, Geneva, Switzerland, 2014.

Zhang, Y., Yi, F., Kong, W., and Yi, Y.: Slope characterization in combining analog and photon count data from atmospheric lidar measurements, Appl. Opt., 53, 7312-7320, 2014
Zoogman, P., Jacob, D. J., Chance, K., Liu, X., Lin, M., Fiore, A., and Travis, K.: Monitoring high-ozone events in the US Intermountain West using TEMPO geostationary satellite observations, Atmos. Chem. Phys., 14, 6261-6271, https://doi.org/10.5194/acp-14-6261-2014, 2014. 